\title{
Impact of eaves on cross-ventilation of a generic isolated leeward sawtooth roof building: windward eaves, leeward eaves and eaves inclination
}

\author{
J.I. Perén ${ }^{\mathrm{a}, \mathrm{b}, 1}$, T. van $\operatorname{Hooff}^{\mathrm{c}}$, B.C.C. Leite ${ }^{\mathrm{a}}$, B. Blocken ${ }^{\mathrm{b}, \mathrm{c}}$ \\ ${ }^{a}$ Civil Construction Engineering Department, Polytechnic School of the University of São Paulo - USP, \\ Av. Prof. Luciano Gualberto, travessa $2 \mathrm{n}^{\circ} 83$ - CEP 05508-900 - São Paulo - SP, Brazil. \\ ${ }^{\mathrm{b}}$ Building Physics and Services, Eindhoven University of Technology, P.O. Box 513, 5600 MB Eindhoven, \\ The Netherlands. \\ ${ }^{\mathrm{c}}$ Building Physics Section, Leuven University, Kasteelpark Arenberg 40, P.O. Box 2447, 3001 Leuven, \\ Belgium.
}

\section{Graphical abstract}

\section{Impact of windward and leeward eaves on cross-ventilation}

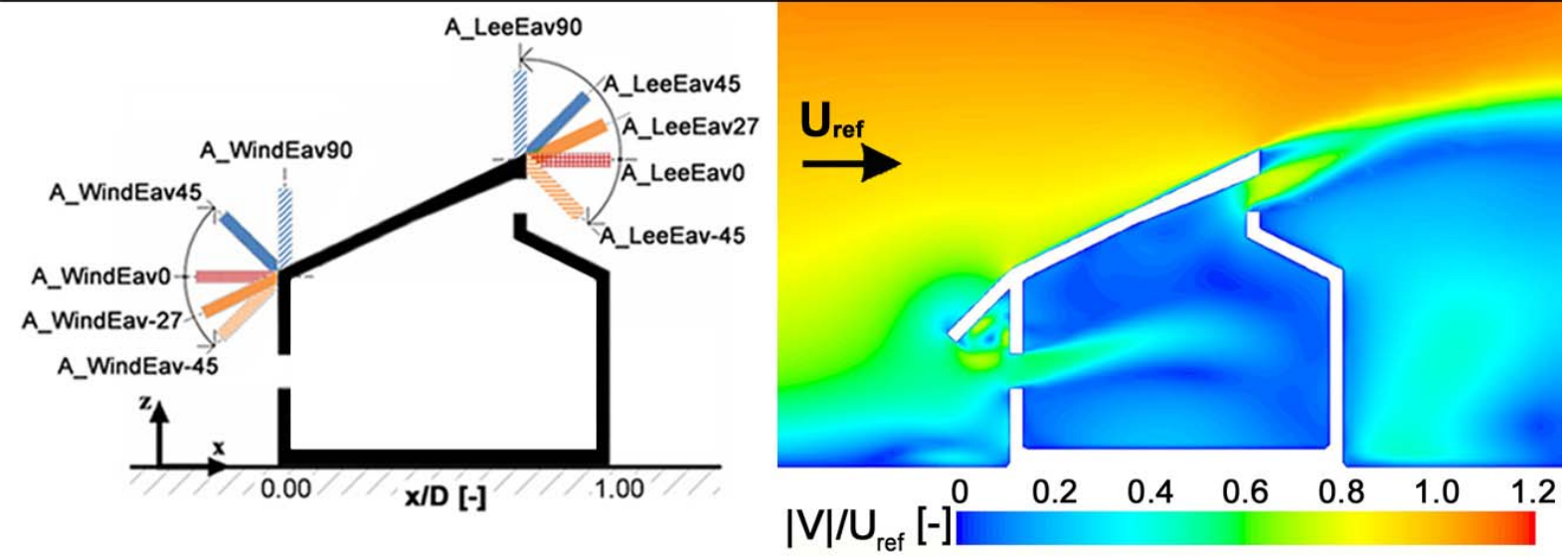

\section{Highlights}

- CFD simulations of natural cross-ventilation flow with 3D steady RANS simulations.

- Influence of windward and leeward eaves on flow rate and velocity.

- Eaves have a large effect on the static pressure distribution on windward facade.

- Windward eaves have a much larger effect than leeward eaves.

- The angle of the eaves determines the effect on flow rate (increase or decrease).

\footnotetext{
${ }^{1}$ Corresponding author: E-mail address: j.i.peren.montero@tue.nl; jiperen@usp.br Tel.: +31 (0) 402473667 Fax +31 (0)40 243 8595. PO Box 513, 5600 MB, Eindhoven.
} 


\title{
Impact of eaves on cross-ventilation of a generic isolated leeward sawtooth roof building: windward eaves, leeward eaves and eaves inclination
}

\author{
J.I. Perén ${ }^{\mathrm{a}, \mathrm{b}, 2}$, T. van Hooff ${ }^{\mathrm{c}}$, B.C.C. Leite ${ }^{\mathrm{a}}$, B. Blocken ${ }^{\mathrm{b}, \mathrm{c}}$ \\ ${ }^{a}$ Civil Construction Engineering Department, Polytechnic School of the University of São Paulo - USP, \\ Av. Prof. Luciano Gualberto, travessa 2 no 83 - CEP 05508-900 - São Paulo - SP, Brazil. \\ ${ }^{\mathrm{b}}$ Building Physics and Services, Eindhoven University of Technology, P.O. Box 513, 5600 MB Eindhoven, \\ The Netherlands. \\ ${ }^{\mathrm{c}}$ Building Physics Section, Leuven University, Kasteelpark Arenberg 40, P.O. Box 2447, 3001 Leuven, \\ Belgium.
}

\begin{abstract}
An eaves is a roof extension that can protect the indoor environment from direct solar radiation, the exterior facade from wetting of by wind-driven rain and can be useful to enhance cross-ventilation. This paper evaluates the impact of eaves configuration on wind-driven cross-ventilation of a generic leeward sawtooth roof building. Both the type of eaves (windward versus leeward) and the eaves inclination angles are investigated. Isothermal Computational Fluid Dynamics (CFD) simulations are performed using the 3D steady Reynolds-Averaged Navier-Stokes (RANS) approach. A grid-sensitivity analysis is performed and validation of the CFD results is conducted based on wind-tunnel measurements with Particle Image Velocimetry from literature. The ventilation evaluation is based on the volume flow rates and the indoor mean velocities. The eaves length is $1 / 4$ of the building depth and the inclination is varied between $90^{\circ}$ to $-45^{\circ}$ for both the windward and leeward eaves. The results show that windward eaves with an inclination of $27^{\circ}$ (equal to roof inclination) result in the highest increase of the volume flow rate (15\%) compared to the building without eaves. Furthermore, the flow through the occupied zone is more horizontally directed. Leeward eaves have a smaller influence on the ventilation volume flow rate than windward eaves; the maximum increase in volume flow rate is only $6 \%$ when a $90^{\circ}$ inclination is employed. Application of both (windward and leeward eaves) results in an increase of the volume flow rate of $24 \%$, which is $3 \%$ more than the sum of the increases by the two eaves separately.
\end{abstract}

Keywords: Computational Fluid Dynamics (CFD); Urban physics; Leeward sawtooth-roof geometry; Natural upward cross-ventilation; Eaves configuration; Building envelope optimization.

\section{Introduction}

An eaves is a roof overhang which can be seen as a multi-purpose building component. As an extension of the roof construction, it can protect the building from solar radiation and wind-driven rain. As a result, eaves are commonly used in tropical climates. The solar shading that is provided by eaves can reduce the energy consumption for cooling significantly. Depending on the building, climate and other factors, this reduction can range from $5.3 \%$ [1] to higher than $10 \%$ [2,3]. In addition to their known effects on solar radiation and winddriven rain, eaves can be employed to increase cross-ventilation flow (e.g. [4]).

Several studies focused on the effects of eaves (e.g. [5-7]) and parapets (vertical extension on a roof top) (e.g. $[8,9])$ on wind loads. Other studies evaluated the protection from wind-driven rain (e.g. [10]), snow loads (e.g. $[11,12])$ and the influence of eaves on convective heat transfer in a roof (e.g. [13]). The majority of the studies focusing on wind loads highlighted the potential of eaves and parapets to reduce the underpressure near the roof edges, where flow separation occurs.

Regarding the potential of eaves to reduce the heat gains due to solar radiation some studies analyzed the shading effects of eaves in for example high-rise residential buildings (e.g. [1]), and school buildings (e.g. [4]). However, to the best of our knowledge, only two studies focused on the impact of eaves on the ventilation flow

\footnotetext{
${ }^{2}$ Corresponding author: E-mail address: j.i.peren.montero@tue.nl; jiperen@usp.br Tel.: +31(0) 402473667

Fax $+31(0) 40243$ 8595. PO Box 513, 5600 MB, Eindhoven.
} 
(e.g. $[14,15])$. Kindangen $[14,15]$ performed Computational Fluid Dynamics (CFD) simulations and observed that in buildings with symmetric opening locations (inlet and outlet openings located at the same height) the use of eaves can increase the cross-ventilation flow rate. Unfortunately, the cases in these studies combined the effect of the eaves with other parameters such as the roof inclination angle, roof shape, roof height and roof orientation, which makes it difficult to isolate the impact of the eaves on the ventilation flow from the impact of other parameters. Furthermore, these studies only considered the impact of eaves with a $0^{\circ}$ inclination (horizontal eaves).

There is a clear lack of research on the impact of the eaves configuration (both eaves at the windward and the leeward side of the building) on wind-driven cross-ventilation. This holds particularly for leeward sawtooth roof buildings. In previous studies by the authors [16,17], the impact of the roof inclination angle [16] and the roof shape [17] on cross-ventilation of leeward sawtooth roof buildings were assessed. The present study builds further on these achievements by reporting a detailed and systematic study on the impact of both windward and leeward eaves on wind-driven upward cross-ventilation of a leeward sawtooth roof building. The study is based on isothermal CFD simulations with the 3D steady Reynolds-Averaged Navier-Stokes (RANS) approach. The performance of each eaves configuration (windward, leeward or the combination of both) is evaluated based on the volume flow rate through the building and the mean air velocity ratios in the occupied zone, measured at four different heights: $\mathrm{h}=0.1 \mathrm{~m}, 0.6 \mathrm{~m}, 1.1 \mathrm{~m}$ and $1.7 \mathrm{~m}$, which are considered as reference for the evaluation of thermal comfort conditions of a seated or standing person, at a steady-state and moderate environment, i.e. where the environmental conditions are close to the thermal comfort standards proposed by ISO 7730/2005 [18]. As mentioned above, the results presented in this paper are part of a large research project on the enhancement of wind-driven cross-ventilation of residential buildings by adjusting the roof geometry. For the sake of brevity and to enable a detailed assessment of the flow behavior in and around the building resulting from the addition of eaves, this paper will only focus on this part of the results obtained in this larger research project.

In the past 50 years, CFD has been increasingly developed and applied as a powerful assessment tool in urban physics and wind engineering [19-23], including natural ventilation in buildings [24-28]. While Large Eddy Simulation (LES) is intrinsically superior to steady RANS simulations, due to the higher computational cost and increased model complexity of LES, a detailed review of the literature [19] shows that RANS simulations still constitute the most frequently used computational approach in urban physics and wind engineering, especially in natural ventilation studies [22,24,26-28].

The paper is structured as follows. The building geometry of the reference case is presented in Section 2. Section 3 presents a brief overview of the CFD validation study using wind-tunnel experiments from literature. The computational settings and parameters for the current study are presented in Section 4. The CFD simulation results of the different eaves configurations are analyzed for a windward eaves and subsequently for a leeward eave, the results of which are outlined in Section 5. Section 6 shows the effect of the simultaneous application of both a windward eaves and a leeward eave. Discussion and conclusions are given in Sections 7 and 8 , respectively.

\section{Building geometry: reference case (geometry A)}

Figure 1 shows the front view (Fig. 1a) and vertical cross-section (Fig. 1b) with the building dimensions, and a perspective view (windward and leeward facade) of the leeward sawtooth roof geometry A (Fig. 1c,d). Leeward sawtooth roof geometry A has a straight upward sloping roof and is selected for this sensitivity analysis as a reference case since it reached the highest volume flow rate compared to other leeward sawtooth roof geometries in a previously published paper by the authors [17]. The building dimensions are $3 \times 6 \times 5.7 \mathrm{~m}^{3}$ ( $\left.\mathrm{W} \times \mathrm{L} \times \mathrm{H}\right)$. Both ventilation openings are $0.9 \times 0.63 \mathrm{~m}^{2}(\mathrm{~W} \mathrm{x} \mathrm{H})$; the bottom of the windward opening is located at $\mathrm{z}=1.42$ $\mathrm{m}$, whereas the bottom of the leeward opening is located at $\mathrm{z}=4.6 \mathrm{~m}$. The distance from the window to the side walls is $1.05 \mathrm{~m}$ on both sides. The thickness of the walls is $0.23 \mathrm{~m}$, and the windward facade has a height of 3.55 m.

\section{CFD simulations: validation study}

When performing CFD simulations based on the 3D steady RANS equations, validation is obligatory to determine the accuracy and reliability of the results. The combination of the computational settings and parameters that will be used in the current study have been validated by the authors in a recent publication [16]. Therefore, only a brief overview of the validation study is provided in this section. 


\subsection{Wind-tunnel experiment}

The wind-tunnel measurements by Karava et al. [29] were used for CFD validation. Karava et al. [29] conducted PIV measurements of wind-induced cross-ventilation for a generic isolated building model with symmetric and asymmetric opening positions in the open-circuit atmospheric boundary layer wind tunnel at Concordia University in Montreal, Canada. The dimensions of the 1:200 building model are $0.1 \times 0.1 \times 0.08 \mathrm{~m}^{3}$ (W x D x $\mathrm{H})$ at reduced scale (full-scale dimensions: $20 \times 20 \times 16 \mathrm{~m}^{3}(\mathrm{~W} \times \mathrm{D} \times \mathrm{H})$ ), as shown in Figure $2 \mathrm{a}$ and $2 \mathrm{~b}$. The height of the openings is $0.018 \mathrm{~m}$ ( $3.6 \mathrm{~m}$ full scale), and the location and width of the openings were varied. For this validation study, the building model with the inlet opening at the bottom of the windward facade (with the center of the opening at $\mathrm{h}=0.02 \mathrm{~m}$ ), the outlet opening at the top of the opposite (leeward) facade (with the center of the opening at $\mathrm{h}=0.06 \mathrm{~m}$ ), and with a wall porosity of $10 \%$, was used. The choice of these asymmetric opening positions resembles the situation of the reference case (Fig. 1). The reduced-scale aerodynamic roughness length in the experiments was $\mathrm{z}_{0}=0.025 \mathrm{~mm}$ corresponding to $0.005 \mathrm{~m}$ in full scale [30]. A reference mean wind speed $\mathrm{U}_{\text {ref }}=6.97 \mathrm{~m} / \mathrm{s}$ and a reference turbulence intensity of $10 \%$ were measured at building height $\left(\mathrm{z}_{\mathrm{ref}}=\mathrm{H}\right)$. The turbulence intensity was about $17 \%$ near ground level $(0.012 \mathrm{~m})$ and $5 \%$ at gradient height $(0.738$ $\mathrm{m})$. The PIV measurements were conducted in a horizontal plane at mid-height $(\mathrm{h}=0.04 \mathrm{~m})$ and in the vertical plane of symmetry (Fig. 2b); the latter will be used in this study. For more information related to the wind-tunnel experiments the reader is referred to [29].

\subsection{CFD simulations and validation}

The computational domain follows the best practice guidelines by Franke et al. [31] and Tominaga et al. [32], apart from the upstream length, which is reduced to 3 times the height of the building to limit the development of unintended streamwise gradients [33-35]. The dimensions of the domain are $0.9 \times 1.54 \times 0.48 \mathrm{~m}^{3}(\mathrm{~W} \times \mathrm{D} \times \mathrm{H})$ (scale 1:200, equal to the wind-tunnel experiment) (Fig. 2c). The computational grid is created using the surfacegrid extrusion technique by van Hooff and Blocken [27] and is shown in Figure 2d and 2e (windward and leeward facade view, respectively). The grid resolution resulted from a grid-sensitivity analysis yielding a fully structured hexahedral grid with 770,540 cells. At the inlet of the domain, the vertical approach-flow profiles of mean wind speed $U$, turbulent kinetic energy $k$ and specific dissipation rate $\omega$ are imposed. These are based on the measured incident profiles of mean wind speed $\mathrm{U}$ and longitudinal turbulence intensity $\mathrm{I}_{\mathrm{U}}$. More information on the boundary conditions can be found in Ref. [16]. The commercial CFD code ANSYS Fluent 12 is used to perform the simulations [36]. The 3D steady RANS equations are solved in combination with the shear-stress transport k- $\omega$ model (SST k- $\omega$ ) [37]. The SIMPLE algorithm is used for pressure-velocity coupling, pressure interpolation is second order and second-order discretization schemes are used for both the convection terms and the viscous terms of the governing equations.

\subsection{Validation}

Figure $3 \mathrm{a}$ and $3 \mathrm{~b}$ display the mean velocity vector field in the vertical center plane as obtained by PIV measurements and CFD simulations, respectively. It is observed that the CFD simulations correctly predict the most important flow features such as the standing vortex upstream of the building and specific character of the flow pattern inside the building, with a strong downflow near the inlet opening up to the downstream wall, followed by a strong upflow along this wall, finally leading to an oblique upward flow through the outlet opening. Figure $3 \mathrm{c}$ and $3 \mathrm{~d}$ compare the measured and computed streamwise wind speed ratio $\mathrm{U} / \mathrm{U}_{\text {ref }}$ along a horizontal line going through the middle of the windward opening and along a diagonal line, showing a good agreement between CFD simulation and PIV experiments.

Although the geometry of the building in the wind-tunnel measurements (Fig. 2) and that of the reference building in the present study (Fig. 1) are not identical, there is a sufficient amount of similarity to consider this validation approach applicable for the leeward sawtooth roof reference building: both buildings are isolated, both have only one internal zone, both have two asymmetric openings (lower one in the windward facade and upper one in the leeward) and both are exposed to wind direction perpendicular to the facade with the lower opening. As a result, the salient flow features in the wind-tunnel building will also be present in the reference building.

\section{CFD simulations of different eaves geometries: computational settings and parameters}

In this section the computational model and grid, boundary conditions and solver settings of the CFD model are presented. This CFD model will be employed for the study of the impact of windward and leeward eaves and their inclination angle. 


\subsection{Computational geometry, domain and grid}

The geometry of the computational model of the reference case (leeward sawtooth roof geometry A) is as presented in Section 2 and Figure 1. The computational domain follows the best practice guidelines by Franke et al. [31] and Tominaga et al. [32], apart from the upstream length, which is reduced to 3 times the height of the building to limit the development of unintended streamwise gradients [33-35] (Fig. 4a). The computational grid is created using the surface-grid extrusion technique by van Hooff and Blocken [27] and is shown in Figure 2d and 2e. This technique allows full control over the quality (size, shape) of every grid cell was successfully used in previous studies for simple and more complex building geometries (e.g.[16,17,24,27,28,38,39]). Figure 4 shows the dimensions of the computational domain, a perspective view of the grid on the building and ground surface and perspective views of the grid on the building surfaces (front and back view) for the reference case building (Geometry A). The grid resolution is based on the grid-sensitivity analysis presented in Peren et al. [17]. The total number of cells is 1,961,524 cells for the reference case, and it varies for each configuration due to the inclusion of the windward and/or leeward eaves, ranging from 1.9 to 2.4 million cells.

\subsection{Boundary conditions}

At the inlet of the domain, vertical profiles of the mean wind speed $U$, turbulent kinetic energy $(\mathrm{k})$ and specific dissipation rate $(\omega)$ are imposed. The wind direction is perpendicular to the windward building facade. The mean wind speed profile is given by the logarithmic law (Eq. 1):

$$
U(z)=\frac{u_{A B L}^{*}}{\kappa} \ln \left(\frac{z+z_{0}}{z_{0}}\right)
$$

with $\mathrm{z}_{0}=0.1 \mathrm{~m}, \mathrm{u}_{\mathrm{ABL}}^{*}$ is the atmospheric boundary layer (ABL) friction velocity, $\kappa$ is the von Karman constant $(0.42)$ and $z$ the height coordinate. The value of $u^{*}{ }_{A B L}$ is determined based on the values of the reference velocity ( $\mathrm{U}_{\text {ref }}$ ) at building height $\left(\mathrm{z}_{\mathrm{ref}}=\mathrm{H}\right)$, which are $\mathrm{U}_{\mathrm{ref}}=12.48 \mathrm{~m} / \mathrm{s}$, and $\mathrm{H}=5.7 \mathrm{~m}$, yielding a building Reynolds number of 500,000. To represent a more realistic wind velocity profile, corresponding to "roughly open country" according to the updated Davenport roughness classification by Wieringa [40], the aerodynamic roughness length is higher than in the validation study. The turbulent kinetic energy $\mathrm{k}$ is calculated from the mean wind speed $\mathrm{U}(\mathrm{z})$ and the streamwise turbulence intensity $\mathrm{I}_{\mathrm{u}}(\mathrm{z})$ (with a value of $15 \%$ at the top of the building model (at $\mathrm{z}_{\mathrm{ref}}$ ) and $45 \%$ at ground level) using Eq. (2):

$$
k(z)=a\left(I_{U}(z) U(z)\right)^{2}
$$

In this equation, $\mathrm{I}_{\mathrm{u}}$ is the measured streamwise turbulence intensity and "a" is a parameter ranging from 0.5 to $1.5[24,32]$. The value $\mathrm{a}=0.5$ is used, as in the validation study. The specific dissipation rate $\omega$ is given by Eq. (3), where $\mathrm{C}_{\mu}$ is an empirical constant taken equal to 0.09 , and the turbulence dissipation rate $\varepsilon$ is given by Eq. (4).

$$
\begin{aligned}
& \omega(z)=\frac{\varepsilon(z)}{C_{\mu} k(z)} \\
& \varepsilon(z)=\frac{u_{A B L}^{* 3}}{\kappa\left(z+z_{0}\right)}
\end{aligned}
$$

At the ground and building surfaces, the standard wall functions by Launder and Spalding [41] are used in conjunction with the sand-grain based roughness $\left(\mathrm{k}_{\mathrm{s}}\right)$ modification defined by Cebeci and Bradshaw [42]. For the ground surfaces, the values of the roughness parameters, i.e. the sand-grain roughness height $\left(\mathrm{k}_{\mathrm{s}}=0.14 \mathrm{~m}\right)$ and the roughness constant $\left(\mathrm{C}_{\mathrm{s}}=7\right)$, are determined by their the relationship with the aerodynamic roughness length $\mathrm{z}_{0}$ derived by Blocken et al. [33]:

$$
k_{s}=\frac{\left(9.793 z_{0}\right)}{C_{s}}
$$


For the building surface the value of the sand-grain roughness height is zero $\left(\mathrm{k}_{\mathrm{S}}=0 \mathrm{~m}\right)$. At the outlet plane, zero static gauge pressure is applied and at the top and lateral sides of the domain a symmetry condition is imposed, i.e. zero normal velocity and zero normal gradients of all variables.

As recommended by Blocken et al. [33,34], a simulation in an empty computational domain is performed to assess the extent of unintended streamwise gradients (i.e. horizontal inhomogeneity) in the vertical mean wind speed profile and the turbulence profiles. Figure 5 shows the profiles of $U, k$ and $\omega$ at the inlet (inlet profiles) and at the location where the building will be positioned (incident profiles). It can be seen that streamwise gradients are absent for the mean wind speed profile. The profiles of $\mathrm{k}$ and $\omega$ do show some streamwise gradients, however, these are relatively limited.

\subsection{Solver settings}

The commercial CFD code ANSYS Fluent 12 [36] is used to perform the isothermal simulations. The 3D steady RANS equations are solved in combination with the shear-stress transport k- $\omega$ model (SST k- $\omega$ model) [37]. The SIMPLE algorithm is used for pressure-velocity coupling, pressure interpolation is second order and secondorder discretization schemes are used for both the convection terms and the viscous terms of the governing equations. Convergence is assumed to be obtained when all the scaled residuals level off and reach a minimum of $10^{-6}$ for $\mathrm{x}$, y momentum, $10^{-5}$ for $\mathrm{z}$ momentum and $10^{-4}$ for $\mathrm{k}, \varepsilon$ and continuity. As also observed by Ramponi and Blocken [24], the simulations show oscillatory convergence. To obtain a reliable steady value of the solution variables, the results are monitored over 10,400 iterations and the variables are calculated by averaging over 400 iterations $(10,000-10,400)$, after the simulation reached a statistically stationary solution.

\section{CFD simulations of different eaves geometries: results}

The windward and the leeward eaves are added to the reference case, as shown in Figure 6 . The effect of the windward and leeward eaves on the ventilation, for a normal wind incidence angle $\left(\varphi=0^{\circ}\right)$ are studied independently from each other. The ventilation performance of the eaves cases is assessed based on the volume flow rate through the building and the average non-dimensional velocity magnitude $\left(|\mathrm{V}| / \mathrm{U}_{\text {ref }}\right)$ along four horizontal lines at four different heights $(\mathrm{h})$ from the ground floor; i.e. $\mathrm{h}=0.1 \mathrm{~m}, 0.6 \mathrm{~m}, 1.1 \mathrm{~m}$, and $1.7 \mathrm{~m}$. Furthermore, the airflow pattern around and inside the building is analyzed.

The cases are designated as "A", referring to the reference case A, followed by the word "WindEav" or "LeeEav", referring to windward eaves or leeward eaves, respectively. The number following "Eav" is related to the inclination angle of the eaves $\left(-45^{\circ},-27^{\circ}, 0^{\circ}, 27^{\circ}, 45^{\circ}, 90^{\circ}\right)$. The negative or positive sign indicates an eaves rotation downwards or upwards with respect to the horizontal position (Fig. 6b). All the studied windward and leeward eaves building cases have the same internal volume, the same inlet and outlet opening size, and the same inlet and outlet opening location.

\subsection{Impact of windward eaves on ventilation}

\subsubsection{Volume flow rate}

Figure 7a shows that the windward eaves configuration has a significant impact on the volume flow rate. Windward eaves with inclination angles lower than $0^{\circ}$ increase the volume flow rate compared to the reference case. For instance, windward eaves with the same inclination angle as the roof $\left(-27^{\circ}\right.$; A_WindEav- 27$)$ increase the volume flow rate by $15 \%$. For case A WindEav $-45\left(-45^{\circ}\right)$, this increase is $8 \%$. However, windward eaves with inclination angles higher than $0^{\circ}$ decrease the volume flow rate; windward eaves with an angle of $90^{\circ}$ (A_WindEav90) have the worst performance (84\%) and windward eaves with an angle of $45^{\circ}$ (A_WindEav45) result in a decrease of the volume flow rate to $90 \%$ (10\% decrease). These results indicate that large parapets located at the lower part of the roof, as is the case for the windward eaves configuration with an angle of $90^{\circ}$ (A_WindEav90), should be avoided from a ventilation point of view. Note that eaves with an angle of $0^{\circ}$ (A_WindEav0), i.e. horizontal eaves, result in a volume flow rate which is almost equal (99\%) to the situation without eaves.

\subsubsection{Air velocity}

The impact of windward eaves on the non-dimensional velocity magnitude $\left(|\mathrm{V}| / \mathrm{U}_{\mathrm{ref}}\right)$ along four horizontal lines, located at a height of $\mathrm{h}=0.1 \mathrm{~m}, 0.6 \mathrm{~m}, 1.1 \mathrm{~m}$ and $1.7 \mathrm{~m}$ from the internal floor (see Fig. $7 \mathrm{~b}$ ), is shown in Figure 
7c-f, by comparing the case with the highest volume flow rate (A_WindEav-27) with the reference case (A). The non-dimensional velocity magnitude in case A_WindEav-27 is increased in the higher level of the occupancy zone (i.e., at $\mathrm{h}=0.6 \mathrm{~m}, 1.1 \mathrm{~m}$ and $1.7 \mathrm{~m}$ ), in almost the whole internal region. For example, Figure $7 \mathrm{~d}$ shows that the velocity magnitude increases over the last part of the horizontal centerline (from $0.5<\mathrm{x} / \mathrm{D}<1.0$ ). Figure $7 \mathrm{e}$ and $7 \mathrm{f}$ clearly indicate that the indoor mean velocity is higher along the horizontal centerline at $\mathrm{h}=1.1 \mathrm{~m}$ and at $\mathrm{h}=1.7 \mathrm{~m}$ in the occupied zone. On the other hand, Figure $7 \mathrm{c}$ shows that the indoor mean velocity at $\mathrm{h}=0.1 \mathrm{~m}$ is lower than in the reference case (A).

\subsubsection{Airflow pattern}

To provide a more elaborate analysis of the effect of the eaves configuration on the flow pattern around and inside the building, Figures 8 and 9 show contours of the pressure coefficient $\left(C_{P}\right)$ and non-dimensional velocity magnitude $\left(|\mathrm{V}| / \mathrm{U}_{\text {ref }}\right)$ for all cases. The pressure coefficient $\mathrm{C}_{\mathrm{P}}$ is calculated as follows:

$C_{P}=\frac{\left(P-P_{0}\right)}{\left(0.5 \rho U_{r e f}^{2}\right)}$

where $P$ is the static pressure, $P_{0}$ the reference static pressure, $\rho$ the density of air $\left(=1.225 \mathrm{~kg} / \mathrm{m}^{3}\right.$ : International Standard Atmosphere (ISA); dry air, $\theta_{\mathrm{a}}=15^{\circ} \mathrm{C}, \mathrm{p}_{0}=101,325 \mathrm{~Pa}$ [43]), and $\mathrm{U}_{\text {ref }}$ is the approach-flow wind speed at building height $\left(\mathrm{U}_{\mathrm{ref}}=12.48 \mathrm{~m} / \mathrm{s}\right.$ at $\left.\mathrm{z}_{\mathrm{ref}}=5.7 \mathrm{~m}\right)$.

Figures 8 shows that windward eaves with inclination angles higher than $0^{\circ}$ increase the overpressure in front of the building but that they decrease the (absolute value of the) underpressure behind the building. The net result is the lower airflow rate shown in Figure 7a. The static pressure increase in front of the building is caused by the larger blockage of the flow by the building with eaves [34, 44-46]. The decrease of the absolute value of the static pressure behind the building is due to the changed flow separation. Indeed, due to the presence of the eaves, the flow separates at the top of these eaves, and seems to not reattach anymore to the roof, or only near the end of the roof. Figure 8 also shows that the direction of the jet entering the building is not significantly influenced by the presence of windward eaves.

Figure 9 shows that windward eaves with inclination angles lower than $0^{\circ}$ decrease the overpressure in front of the building, while the (absolute value of the) underpressure behind the building remains approximately the same. The net result is that the magnitude of the pressure difference over the building decreases. At first sight, this should lead to a decrease of the flow rate through the building. However, the simulation results in Figure 7a show an increase. The reason for this is the direction of the flow through the inlet opening. Figures $9 \mathrm{~d}$ and $9 \mathrm{f}$ clearly show that the inlet jet has a more horizontal direction. This leads to a large effective opening area, or, in other words, a larger discharge coefficient. The changed direction of the inlet jet is the direct result of the altered static pressure distribution in front of the building. As can be seen in Figures $9 \mathrm{c}$ and $9 \mathrm{e}$, this distribution is more equal above and below the opening than in Figure 8a.

\subsection{Impact of leeward eaves on ventilation}

\subsubsection{Volume flow rate}

Leeward eaves have a smaller impact on the volume flow rate than windward eaves, as can be seen by comparing Figure 7a with Figure 10a. Leeward eaves with an inclination angle of $45^{\circ}$ (A_LeeEav45) and $90^{\circ}$ (A_LeeEav90) result in an increase of the volume flow rate with $5 \%$ and $6 \%$ compared to the reference case, respectively. However, leeward eaves with an inclination angle of $0^{\circ}$ (A_LeeEav0) and $-45^{\circ}$ (A_LeeEav-45) result in a decrease of the volume flow rate with $8 \%$ and $9 \%$, respectively. The leeward eaves with an inclination angle equal to that of the roof (A_LeeEav27) results in a volume flow rate that is equal to that of the reference case. These results show that interferences or blocking objects near the outlet opening in the wake of the building should be avoided. In other words, leeward eaves with angles smaller than the roof angle should not be applied. Moreover, leeward eaves with inclination angles higher than the roof angle $\left(27^{\circ}\right)$ are recommended to increase the volume flow rate.

\subsubsection{Air velocity}

Figure 10c-f shows a comparison of the non-dimensional velocity magnitude $\left(|\mathrm{V}| / \mathrm{U}_{\text {ref }}\right)$ inside the building 
between case A_LeeEav90, which is the case with the highest volume flow rate, and the reference case. It can be seen that the influence of a leeward eaves is smaller than of a windward eaves; however, there is still a clear impact on the mean indoor air velocities. The leeward eaves (A_LeeEav90) increases the indoor velocity mainly in the lower part of the occupied zone (i.e. at $\mathrm{h}=0.6 \mathrm{~m}$; Fig. 10d). Figure 10e-f shows that the velocities in the upper part of the enclosure are nearly equal to those in the reference case.

\subsubsection{Airflow pattern}

Figures 11 and 12 show contours of the pressure coefficient $\left(\mathrm{C}_{\mathrm{P}}\right)$ and non-dimensional velocity magnitude $\left(\mid \mathrm{V} / / \mathrm{U}_{\text {ref }}\right)$ for all cases. Figure 11 shows that leeward eaves with inclination angles higher than the roof slope have little effect on the overpressure in front of the building but that they increase the (absolute value of the) underpressure behind the building. The net result is the higher airflow rate as shown in Figure 10a. The increase of the absolute value of the static pressure behind the building is due to the changed flow separation. Indeed, due to the presence of the eaves, the flow separates at the top of these eaves, and this yields a larger wake with stronger underpressure. Figure 11 also shows that the direction of the jet entering the building is not significantly influenced by the presence of these leeward eaves.

Figure 12 shows that leeward eaves with inclination angles lower than the roof slope also have little effect on the overpressure in front of the building, but that they decrease the (absolute value of the) underpressure behind the building remains. The net result is the lower airflow rate shown in Figure 10a. Figure 12 also shows that the direction of the jet entering the building is not significantly influenced by the presence of the leeward eaves.

\section{Combination of windward and leeward eaves}

Figure 13 shows the volume flow rates for case A (reference case) and for the two cases selected to evaluate the coupled effect of windward and leeward eaves: A_WindEav-27_LeeEav27 and A_WindEav-27_LeeEav90. These two cases combine windward eaves with an inclination angle of $-27^{\circ}$ (A_WindEav-27), which showed the best performance in Section 5.1, with two different leeward eaves configurations: (a) A_LeeEav27 and, (b) A_LeeEav90. The former has the same inclination angle as the roof; i.e. $27^{\circ}$, while the latter is the best leeward eaves configuration, as presented in Section 5.2. Note that the aim of this study is to maximize the volume flow rate through a naturally ventilated building. Therefore, possible combinations of other windward and leeward eaves angles have not been analyzed, since the individual performance of other windward and leeward eaves inclination angles is inferior to that of aforementioned angles. Figure 13 shows the increase in the volume flow rate obtained by the coupled effect of windward and leeward eaves. From the two cases analyzed, A_WindEav27 LeeEav90 yields the highest increase, with a $24 \%$ higher volume flow rate compared to the reference case (A). It shows that the coupled effect of the windward and the leeward eaves for case A_WindEav-27_LeeEav90 increases the volume flow rate by an additional $3 \%$ compared to the sum of the isolated increases; i.e. $15 \%$ for A_WindEav-27 and $6 \%$ for A_LeeEav90. The A_WindEav-27_LeeEav27 case results in the same increase of the volume flow rate as in the isolated case A_WindEav-27, which can be explained by the fact that the volume flow rate did not increase for A_LeeEav27 (see Section 5.2.1).

Figure 14 displays the pressure coefficient $\mathrm{C}_{\mathrm{P}}$ and the non-dimensional velocity magnitude $\left(|\mathrm{V}| / \mathrm{U}_{\text {ref }}\right)$ inside and around the building for the reference case and the cases A_WindEav-27_LeeEav90 and A_WindEav27_LeeEav27. Figure 14a,c,e shows that the size and magnitude of the underpressure zone are clearly highest for the case A_WindEav-27_LeeEav90. Figure 14d and 14f again show that for the cases A_WindEav27_LeeEav27 and A_WindEav-27_LeeEav90 the incoming stream flow follows a more horizontal direction compared to the reference case (Fig. 14b), contributing to a higher airflow rate.

\section{Discussion}

The main goal of this study on upward wind-driven cross-ventilation is to evaluate the impact of the eaves configuration for a normal wind incidence angle $\left(\varphi=0^{\circ}\right)$. First, five windward eaves configurations are evaluated, followed by five leeward eaves configurations. Finally, two cases that have both windward and leeward eaves (A_WindEav-27_LeeEav27, A_WindEav-27_LeeEav90) are analyzed to study the combined effect. It is important to mention the limitations of the current study, which should be addressed in future studies:

- Surrounding buildings can have a large influence on the ventilation flow through the building. Therefore, the impact of surrounding buildings needs to be assessed in future work. 
- Temperature effects (buoyancy) can alter the flow pattern in and around the building, especially when low wind velocities are present. Future studies can focus on the combined effects of wind and buoyancy on the ventilation flow in the building.

- This study focuses on a normal wind incidence angle $\left(\varphi=0^{\circ}\right)$. The impact of wind incidence angles different than $0^{\circ}$ should be considered as well, since this can influence the ventilation performance of the different eaves configurations. For more oblique wind incidence angles it might be necessary to resort to unsteady simulations, such as Large Eddy Simulations (LES) or Detached Eddy Simulation (DES), to accurately predict the transient flow features around the building in general and near the openings in particular, and thus to obtain accurate volume flow rates (e.g. [47,48]).

- Future studies can include other effects of windward and leeward eaves, e.g. the protection of the building interior and exterior from wind-driven rain and solar shading, to provide an integral analysis of the application of eaves to buildings.

\section{Conclusions}

This paper presents numerical simulations to study the impact of windward and leeward eaves on the winddriven cross-ventilation flow in a generic isolated leeward sawtooth roof building. The study is performed by isothermal CFD simulations with the 3D steady RANS approach and the SST k- $\omega$ turbulence model. The computational grid is based on a grid-sensitivity analysis and the computational model is validated using Particle Image Velocimetry (PIV) wind-tunnel measurements from literature. The main conclusions of this paper are:

- Windward eaves with inclination angles lower than $0^{\circ}$ increase the volume flow rate compared to the reference case. The largest increase is obtained when a windward eaves with an inclination angle of $27^{\circ}$ (A_WindEav-27) is applied: $+15 \%$. On the other hand, windward eaves with inclination angles higher than $0^{\circ}$ decrease the volume flow rate with up to $16 \%$ for A_WindEav90. A horizontal eaves $\left(0^{\circ}\right.$ inclination) results in a volume flow rate which is almost equal to the reference case.

- The jet flow that enters the building is more horizontally directed when windward eaves are applied with inclination angles lower than $0^{\circ}$. The different direction is the result of an altered distribution of the static pressure above and below the inlet opening. For a given pressure difference between windward and leeward facade, the more horizontal direction leads to a higher volume flow rate.

- Application of leeward eaves with an inclination angle of $45^{\circ}$ (A_LeeEav45) and $90^{\circ}$ (A_LeeEav90) results in an increase of the volume flow rate with $5 \%$ and $6 \%$, respectively. Leeward eaves with an inclination angle of $0^{\circ}$ (A_LeeEav0) and $-45^{\circ}$ (A_LeeEav-45) result in a decrease of the volume flow rate with $8 \%$ and $9 \%$, respectively. A leeward eaves with an inclination angle of $27^{\circ}$ results in the same volume flow rate as in the reference case.

- Interferences or blocking objects near the outlet opening, in the wake of the building, should be avoided. In other words, leeward eaves with angles smaller than the roof angle should not be applied. Moreover, leeward eaves with inclination angles higher than the roof angle $\left(27^{\circ}\right)$ are recommended to increase the volume flow rate.

- In general, to improve the volume flow rate in the studied low-rise leeward sawtooth roof building, the windward eaves inclination angle must be lower than $0^{\circ}$, such as $-27^{\circ}$ or $-45^{\circ}$, and the inclination of the leeward eaves must be higher than $27^{\circ}$, for instance $45^{\circ}$ or $90^{\circ}$. The coupled effect of the eaves (windward and leeward eaves working together) can be larger than the individual effects: applying the best performing windward and leeward eaves simultaneously (i.e. A_WindEav-27_LeeEav90) can increase the volume flow rate with an additional $3 \%$ compared to the sum of the two individual effects.

\section{Acknowledgements}

This work was supported by The Coordination for the Improvement of Higher Level Personnel (CAPES), Brazil, The Civil Construction Engineering Department, Polytechnic School of the University of São Paulo (USP), Brazil and the unit Building Physics and Services of the Department of the Built Environment at Eindhoven University of Technology in the Netherlands.

Twan van Hooff is currently a postdoctoral fellow of the Research Foundation - Flanders (FWO) and acknowledges its financial support (project FWO 12R9715N).

\section{References}

[1] Bojić M. Application of overhangs and side fins to high-rise residential buildings in Hong Kong. Civ Eng Environ Syst 2006;23:271-85. doi:10.1080/10286600600888532. 10. 
[2] Song WT, Lin G, Wu Z-Y. Computer-supported methodologies to estimate the eave effect on building energy consumption. Proc. 2014 IEEE 18th Int. Conf. Comput. Support. Coop. Work Des. CSCWD, 2014, p. 721-6. doi:10.1109/CSCWD.2014.6846934.

[3] Raeissi S, Taheri M. Optimum overhang dimensions for energy saving. Build Environ 1998;33:293-302.

[4] Chiang WH, Hsu HH, Huang JS. Façade design effect on cross-ventilation in Taiwanese school buildings. J Green Build 2013;8:90-111. doi:10.3992/jgb.8.2.90.

[5] Robertson AP. Effect of eaves detail on wind pressures over an industrial building. J Wind Eng Ind Aerodyn 1991;38:325-33.

[6] Stathopoulos T, Luchian H. Wind-induced forces on eaves of low buildings. J Wind Eng Ind Aerodyn 1994;52:249-61. doi:10.1016/0167-6105(94)90051-5.

[7] Savory E, Dalley S, Toy N. The effects of eaves geometry, model scale and approach flow conditions on portal frame building wind loads. J Wind Eng Ind Aerodyn 1992;43:1665-76. doi:10.1016/01676105(92)90576-V.

[8] Stathopoulos T, Baskaran A. Wind pressures on flat roofs with parapets. J Struct Eng ASCE 1987;113:2166-80.

[9] Kopp GA, Surry D, Mans C. Wind effects of parapets on low buildings: Part 1. Basic aerodynamics and local loads. J Wind Eng Ind Aerodyn 2005;93:817-41. doi:10.1016/j.jweia.2005.08.006.

[10] Ishikawa $\mathrm{H}$. Method for estimating rain-wetting patterns over external walls of low-rise buildings in accordance with shapes and sizes of the eaves overhangs. J Struct Constr Eng 2011;76:1069-75. doi:10.3130/aijs.76.1069.

[11] Tsutsumi T, Sato T, Tomabechi T, Chiba T. Experimental studies of snow condition on louvered eaves of building. AIJ J Technol Des 2010;16:59-62. doi:10.3130/aijt.16.59.

[12] Thiis TK, Barfoed P, Delpech P, Gustavsen A, Hofseth V, Uvsløkk S, et al. Penetration of snow into roof constructions - Wind tunnel testing of different eaves cover designs. J Wind Eng Ind Aerodyn 2007;95:1476-85. doi:10.1016/j.jweia.2007.02.017.

[13] Oztop HF, Varol Y, Koca A. Laminar natural convection heat transfer in a shed roof with or without eaves for summer season. Appl Therm Eng 2007;27:2252-65. doi:10.1016/j.applthermaleng.2007.01.018.

[14] Kindangen JI. Window and roof configurations for comfort ventilation. Build Res Inf 1997;25:218-25. doi:10.1080/096132197370345.

[15] Kindangen J, Krauss G, Depecker P. Effects of roof shapes on wind-induced air motion inside buildings. Build Environ 1997;32:1-11.

[16] Perén JI, van Hooff T, Leite BCC, Blocken B. CFD analysis of cross-ventilation of a generic isolated building with asymmetric opening positions: impact of roof angle and opening location. Build Environ 2015;85:263-76. doi:10.1016/j.buildenv.2014.12.007.

[17] Perén JI, Ramponi R, van Hooff T, Blocken B, Leite BCC. Impact of roof geometry of an isolated leeward sawtooth-roof building on cross-ventilation: Straight, concave, hybrid or convex? Submitted 2014.

[18] International Organization for Standardization. Ergonomics of the thermal environment - Analytical determination and interpretation of thermal comfort using calculation of the PMV and PPD indices and local thermal comfort criteria (ISO 7730:2005). European Committee for Standardization, Brussels, Belgium: 2005.

[19] Blocken B. 50 years of Computational Wind Engineering: Past, present and future. J Wind Eng Ind Aerodyn 2014;129:69-102. doi:10.1016/j.jweia.2014.03.008.

[20] Stathopoulos T. Computational wind engineering: Past achievements and future challenges. J Wind Eng Ind Aerodyn 1997;67-68:509-32. doi:10.1016/S0167-6105(97)00097-4.

[21] Mochida A, Lun IYF. Prediction of wind environment and thermal comfort at pedestrian level in urban area. J Wind Eng Ind Aerodyn 2008;96:1498-527. doi:10.1016/j.jweia.2008.02.033.

[22] Chen Q. Ventilation performance prediction for buildings: A method overview and recent applications. Build Environ 2009;44:848-58. doi:10.1016/j.buildenv.2008.05.025.

[23] Blocken B, Stathopoulos T, Carmeliet J, Hensen JLM. Application of computational fluid dynamics in building performance simulation for the outdoor environment: An overview. J Build Perform Simul 2011;4:157-84. doi:10.1080/19401493.2010.513740.

[24] Ramponi R, Blocken B. CFD simulation of cross-ventilation for a generic isolated building: Impact of computational parameters. Build Environ 2012;53:34-48. doi:10.1016/j.buildenv.2012.01.004.

[25] Kato S, Murakami S, Mochida A, Akabayashi S, Tominaga Y. Velocity-pressure field of cross ventilation with open windows analyzed by wind tunnel and numerical simulation. J Wind Eng Ind Aerodyn 1992;44:2575-86. doi:10.1016/0167-6105(92)90049-G.

[26] Horan JM, Finn DP. Sensitivity of air change rates in a naturally ventilated atrium space subject to variations in external wind speed and direction. Energy Build 2008;40:1577-85. doi:10.1016/j.enbuild.2008.02.013. 
[27] van Hooff T, Blocken B. Coupled urban wind flow and indoor natural ventilation modelling on a highresolution grid: A case study for the Amsterdam Arena stadium. Environ Model Softw 2010;25:51-65. doi:10.1016/j.envsoft.2009.07.008.

[28] van Hooff T, Blocken B. On the effect of wind direction and urban surroundings on natural ventilation of a large semi-enclosed stadium. Comput Fluids 2010;39:1146-55. doi:10.1016/j.compfluid.2010.02.004.

[29] Karava P, Stathopoulos T, Athienitis AK. Airflow assessment in cross-ventilated buildings with operable façade elements. Build Environ 2011;46:266-79. doi:10.1016/j.buildenv.2010.07.022.

[30] Karava P. Airflow prediction in buildings for natural ventilation design: wind tunnel measurements and simulation. Department of Building, Civil and Environmental Engineering, Concordia University, 2008.

[31] Franke J, Hellsten A, Schlunzen KH, Carissimo B. Best Practice Guideline for CFD simulation of flows in the urban environment. Bruss COST 2007. doi:10.1504/IJEP.2011.038443.

[32] Tominaga Y, Mochida A, Yoshie R, Kataoka H, Nozu T, Yoshikawa M, et al. AIJ guidelines for practical applications of CFD to pedestrian wind environment around buildings. J Wind Eng Ind Aerodyn 2008;96:1749-61. doi:10.1016/j.jweia.2008.02.058.

[33] Blocken B, Stathopoulos T, Carmeliet J. CFD simulation of the atmospheric boundary layer: wall function problems. Atmos Environ 2007;41:238-52. doi:10.1016/j.atmosenv.2006.08.019.

[34] Blocken B, Carmeliet J, Stathopoulos T. CFD evaluation of wind speed conditions in passages between parallel buildings - effect of wall-function roughness modifications for the atmospheric boundary layer flow. J Wind Eng Ind Aerodyn 2007;95:941-62. doi:10.1016/j.jweia.2007.01.013.

[35] Blocken B. Computational Fluid Dynamics for Urban Physics: Importance, scales, possibilities, limitations and ten tips and tricks towards accurate and reliable simulations. Build Environ 2015. doi:10.1016/j.buildenv.2015.02.015

[36] ANSYS. Fluent 12 user's guide. Lebanon: Fluent Inc. 2009.

[37] Menter FR. Two-equation eddy-viscosity turbulence models for engineering applications. AIAA J 1994;32:1598-605.

[38] van Hooff T, Blocken B, Aanen L, Bronsema B. A venturi-shaped roof for wind-induced natural ventilation of buildings: Wind tunnel and CFD evaluation of different design configurations. Build Environ 2011;46:1797-807. doi:10.1016/j.buildenv.2011.02.009.

[39] Montazeri H, Blocken B, Janssen WD, van Hooff T. CFD evaluation of new second-skin facade concept for wind comfort on building balconies: Case study for the Park Tower in Antwerp. Build Environ 2013;68:179-92. doi:10.1016/j.buildenv.2013.07.004.

[40] Wieringa J. Updating the Davenport roughness classification. J Wind Eng Ind Aerodyn 1992;41:357-68. doi:10.1016/0167-6105(92)90434-C.

[41] Launder BE, Spalding DB. The numerical computation of turbulent flows. Comput Methods Appl Mech Eng 1974;3:269-89. doi:10.1016/0045-7825(74)90029-2.

[42] Cebeci T, Bradshaw P. Momentum transfer in boundary layers. Hemisphere Publishing Corp. New York: 1977.

[43] ISO 2533. International Organization for Standardization. Standard Atmosphere. International Standards Organization; 1975.

[44] Blocken B, Carmeliet J. The influence of the wind-blocking effect by a building on its wind-driven rain exposure. J Wind Eng Ind Aerodyn 2006;94(2): 101-127.

[45] Blocken B, Stathopoulos T, Carmeliet J. Wind environmental conditions in passages between two long narrow perpendicular buildings. J Aerospace Eng - ASCE. 2008;21(4): 280-287.

[46] Blocken B, Moonen P, Stathopoulos T, Carmeliet J. A numerical study on the existence of the Venturieffect in passages between perpendicular buildings. J Eng Mech - ASCE 2008;134(12): 1021-1028.

[47] Jiang Y, Chen Q. Study of natural ventilation in buildings by large eddy simulation. J Wind Eng Ind Aerodyn 2001;89(13):1155-1178.

[48] Wright NG, Hargreaves DM. Unsteady CFD simulations for natural ventilation. Int J Vent 2006;5(1):1320. 


\section{FIGURE}

a

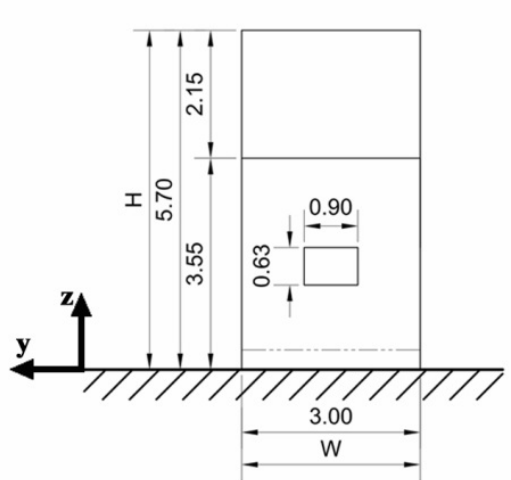

C

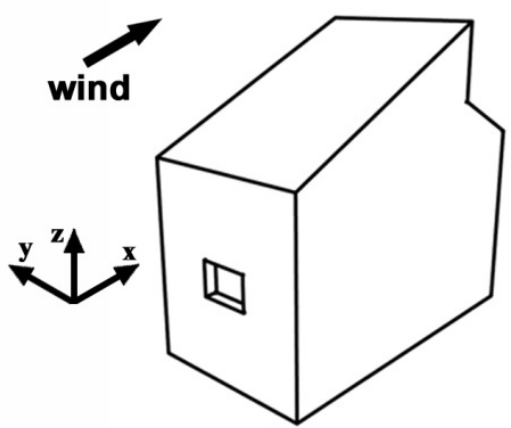

b

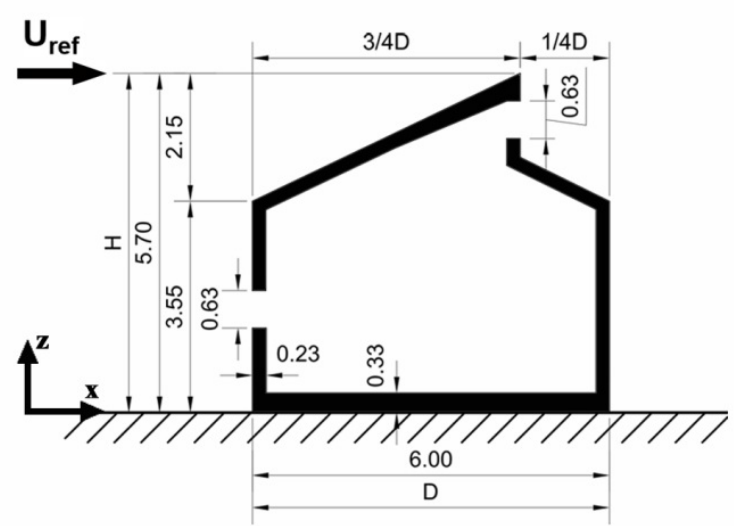

d

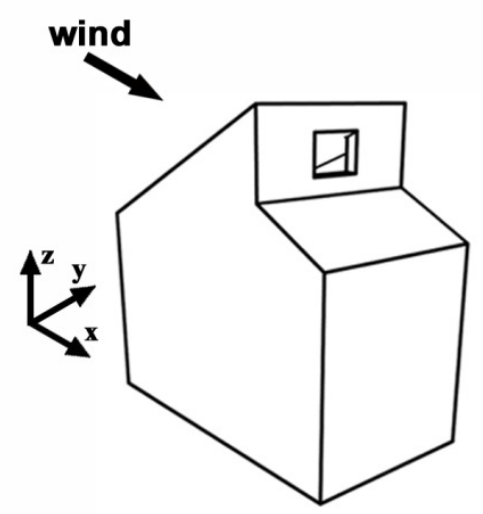

Fig. 1. Overview of geometry of the reference case (geometry A) (dimensions in meters). (a) Front view (windward facade) with opening size and dimensions. (b) Vertical cross-section with opening size and dimensions. Perspective views: (c) windward facade (d) leeward facade. 
a

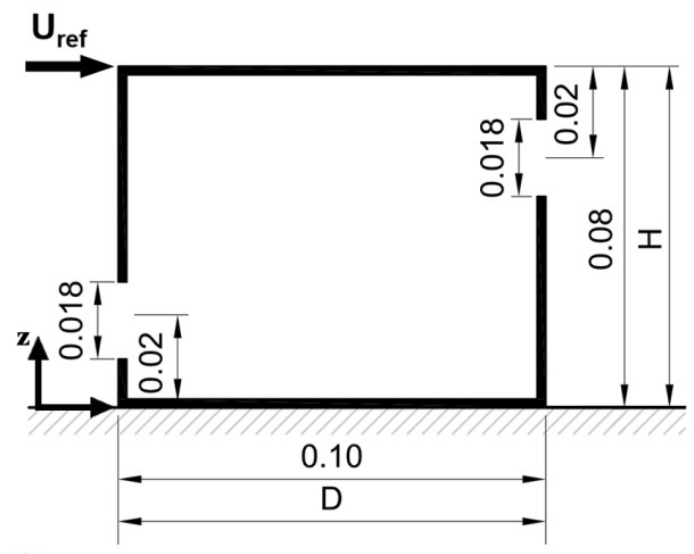

C

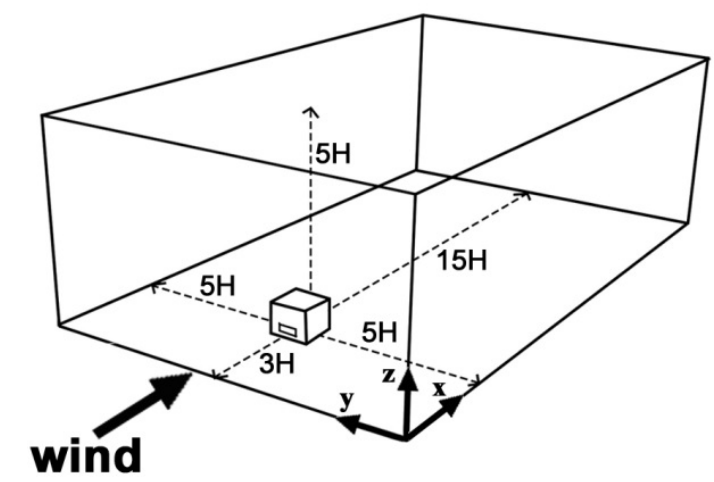

b

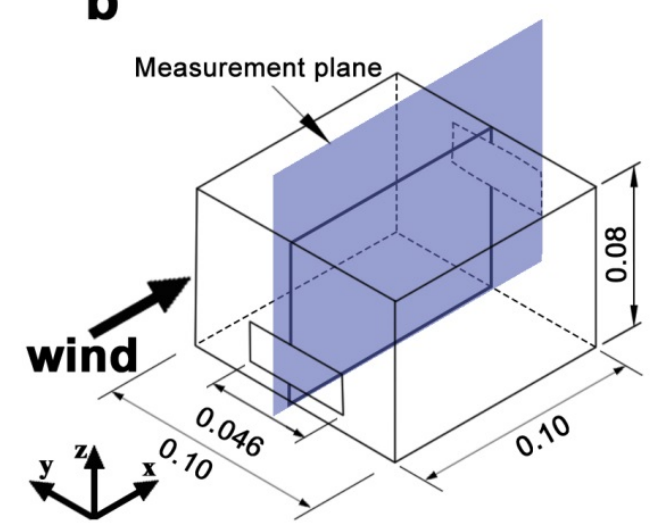

\section{d}

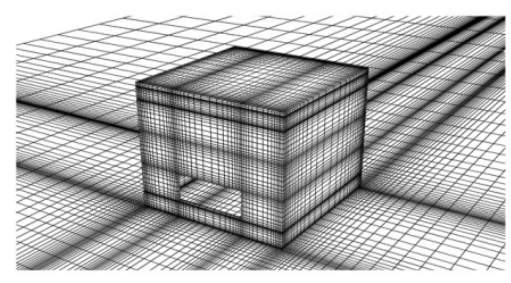

e

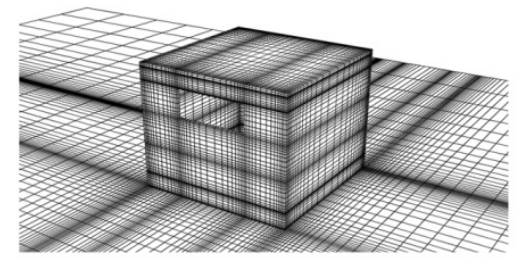

Fig. 2. (a) Vertical cross-section of the reduced-scaled building model as studied by Karava et al. [29] with opening size and dimensions (in meters). (b) Perspective view indicating the measurement plane with dimensions (in meters). (c) Perspective view of the building in its computational domain. $(\mathrm{d}, \mathrm{e})$ Perspective close-up view of the grid $(770,540$ cells) on the building surface and part of the ground: (d) windward facade; (e) leeward facade. 

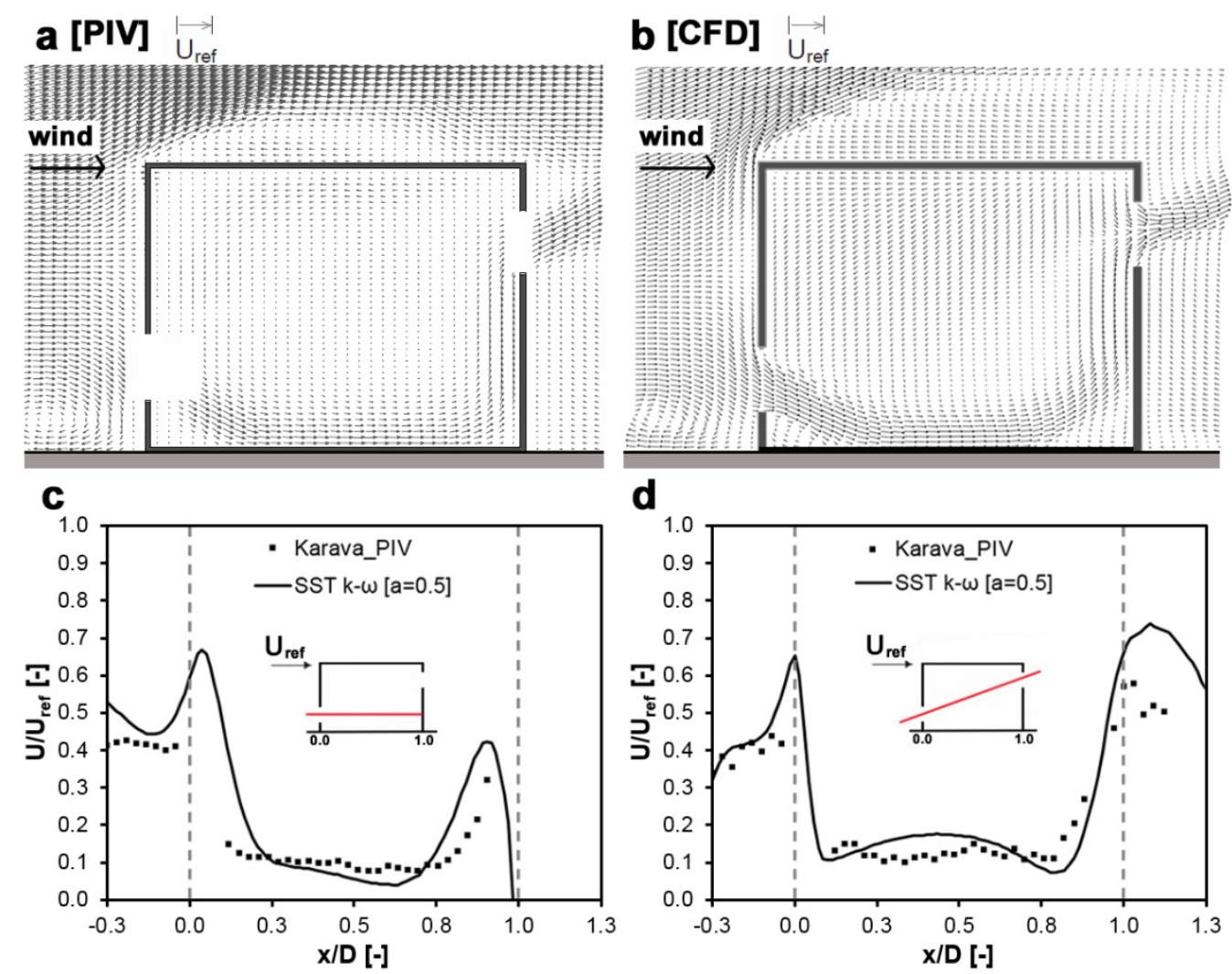

Fig. 3. (a,b) Comparison of the mean velocity in the vertical center plane obtained from: (a) PIV measurements (processed

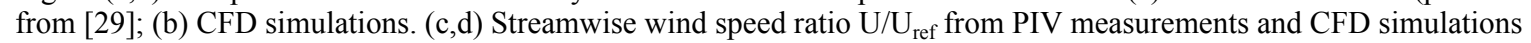
along: (c) horizontal line; and (d) diagonal line [16].
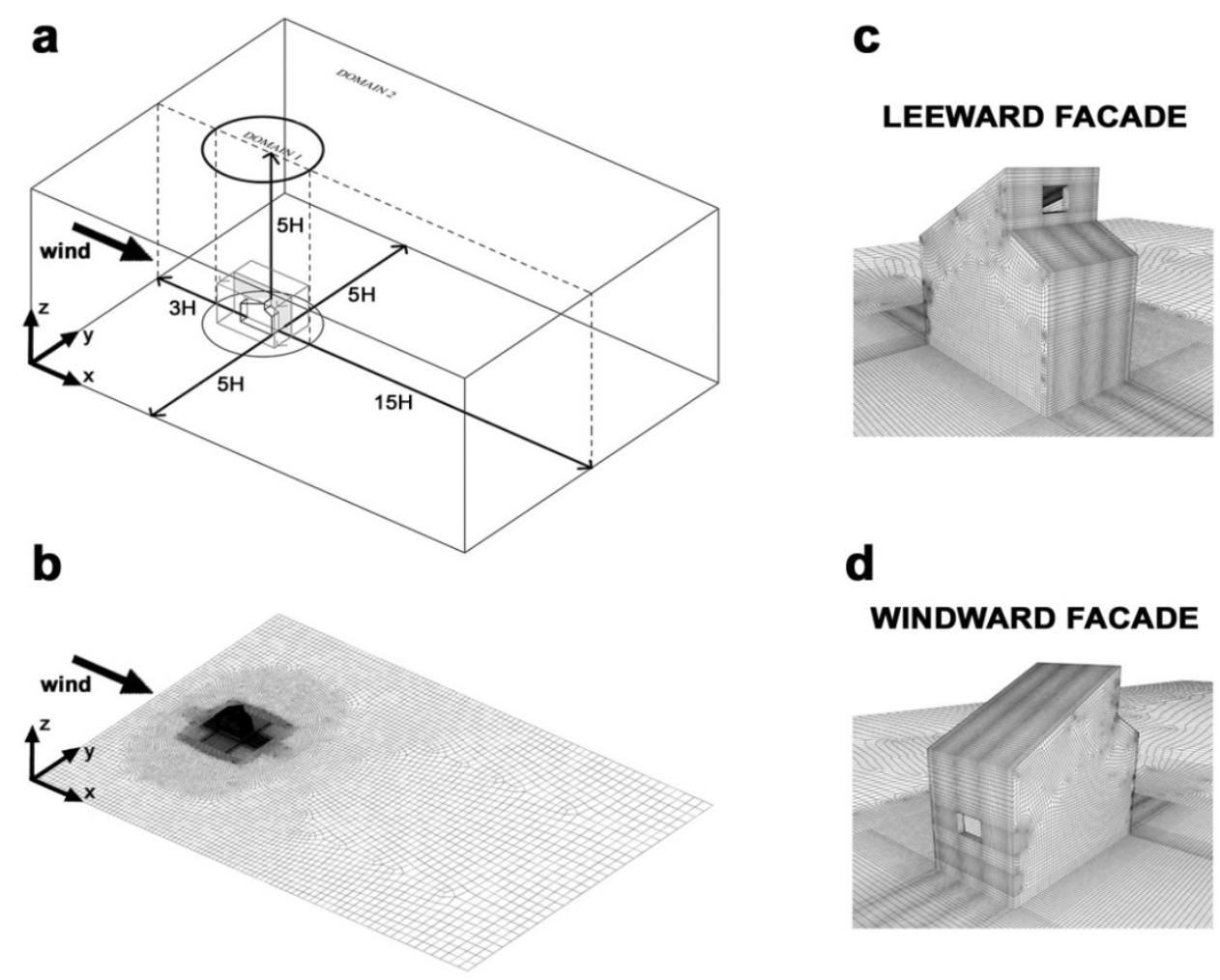

\section{WINDWARD FACADE}

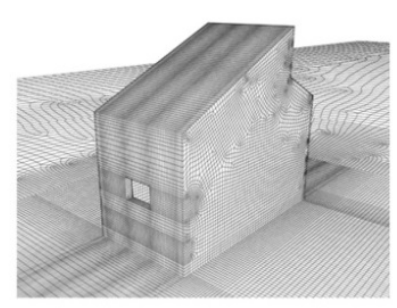

Fig. 4. (a) Perspective view of the reference case building (geometry A) in its computational domain at model scale. (b,c,d) Perspective view of the grid (geometry A) (total number of cells: 1,961,524 cells); (b) View of the computational grid on the building surfaces and on the ground surface; (c) View of the leeward facade (outlet opening); (d) View of the windward facade (inlet opening). 


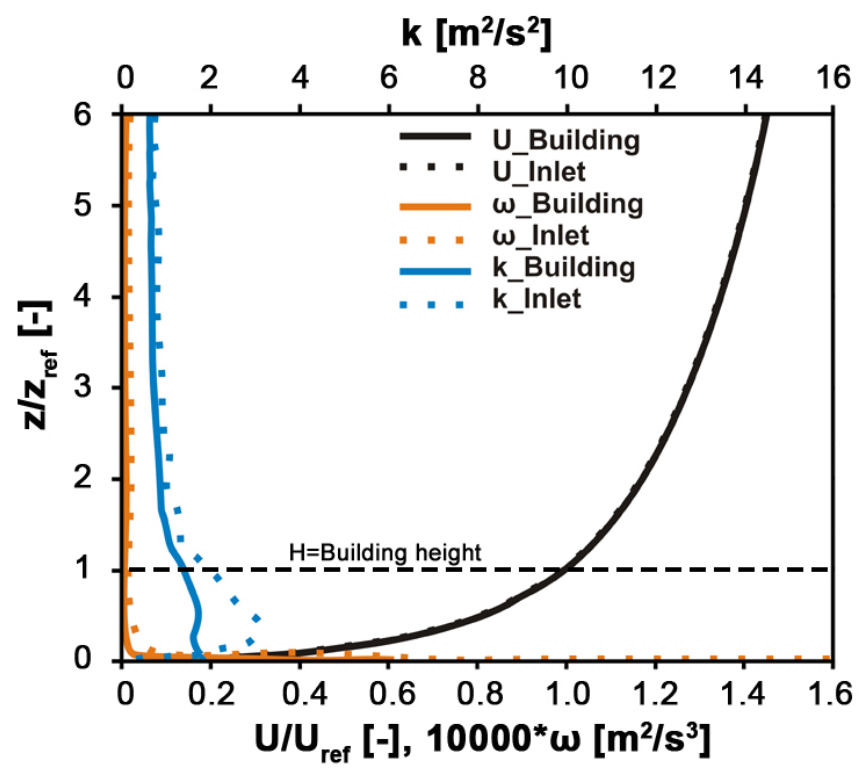

Fig. 5. Horizontal homogeneity analysis: Profiles of the mean wind speed (U), the turbulent kinetic energy (k) and the specific dissipation rate $(\omega)$ at the inlet (dotted line) and at the building position (solid line) in an empty domain. The height of the model $\left(\mathrm{z}_{\mathrm{ref}}=\mathrm{H}\right)$ is $5.7 \mathrm{~m} \mathrm{[17].}$

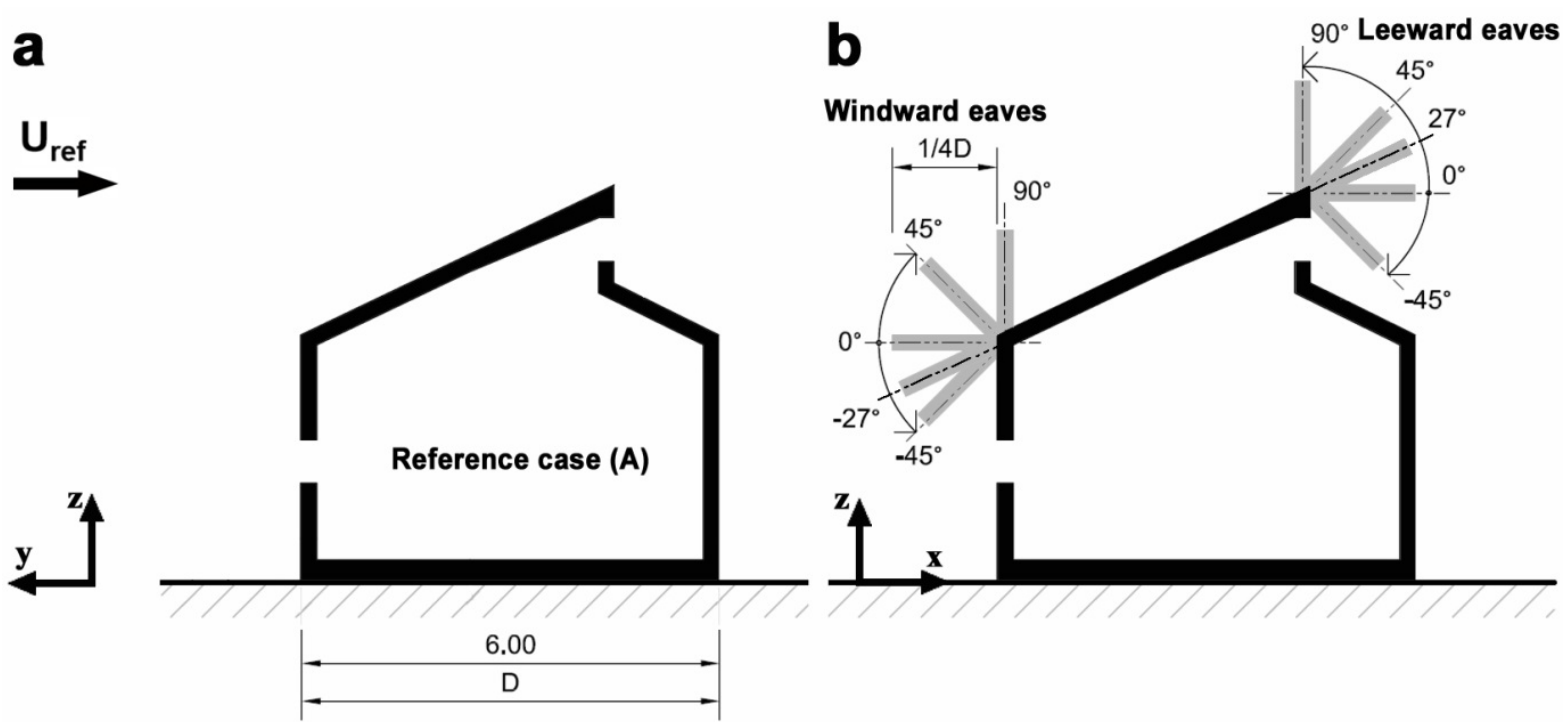

Fig. 6. (a) Vertical cross-section of the reference case (geometry A). (b) Vertical cross-section with schematic indication of the windward and leeward eaves configuration cases. The length of the eaves is $1 / 4 \mathrm{D}$. 

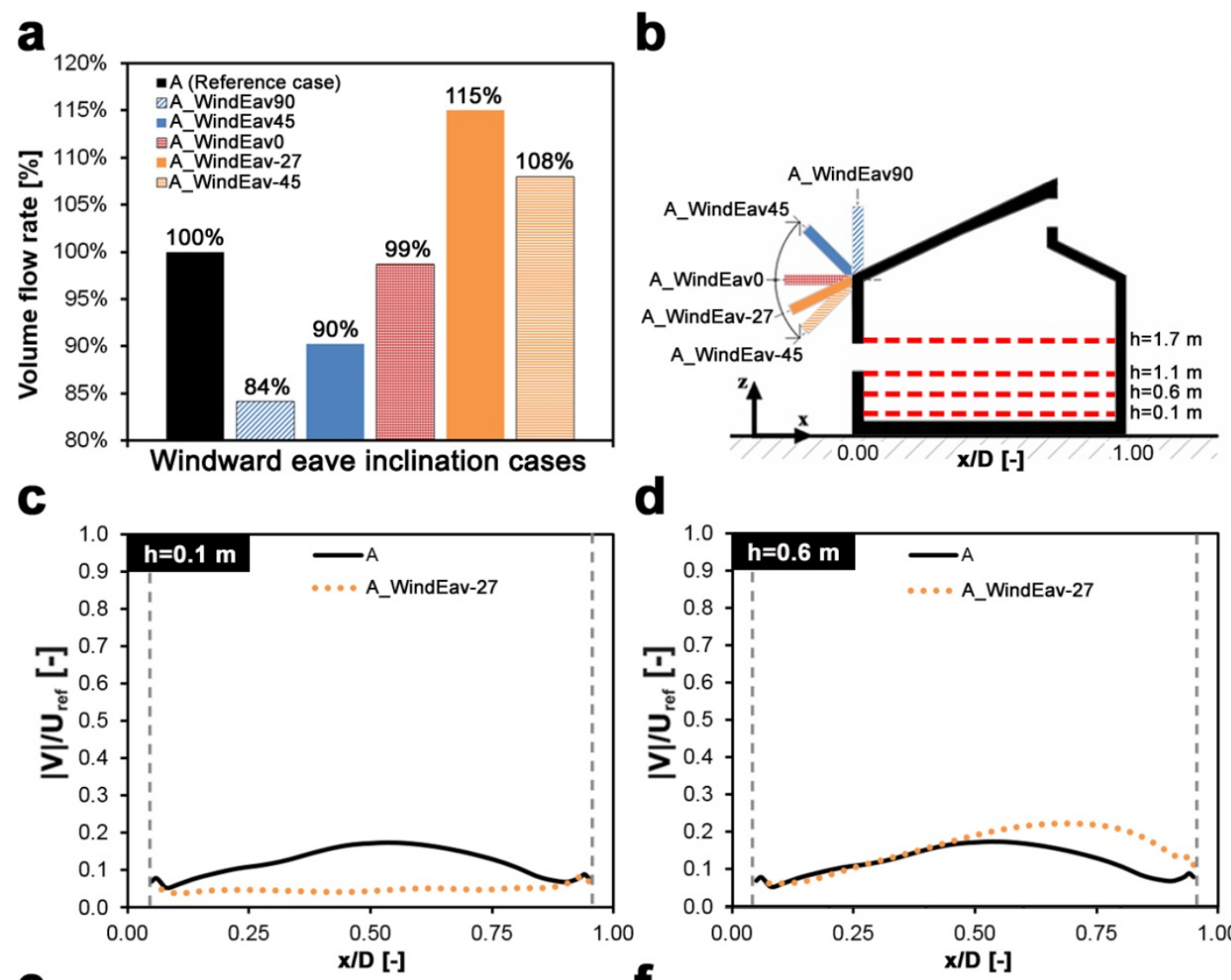

d
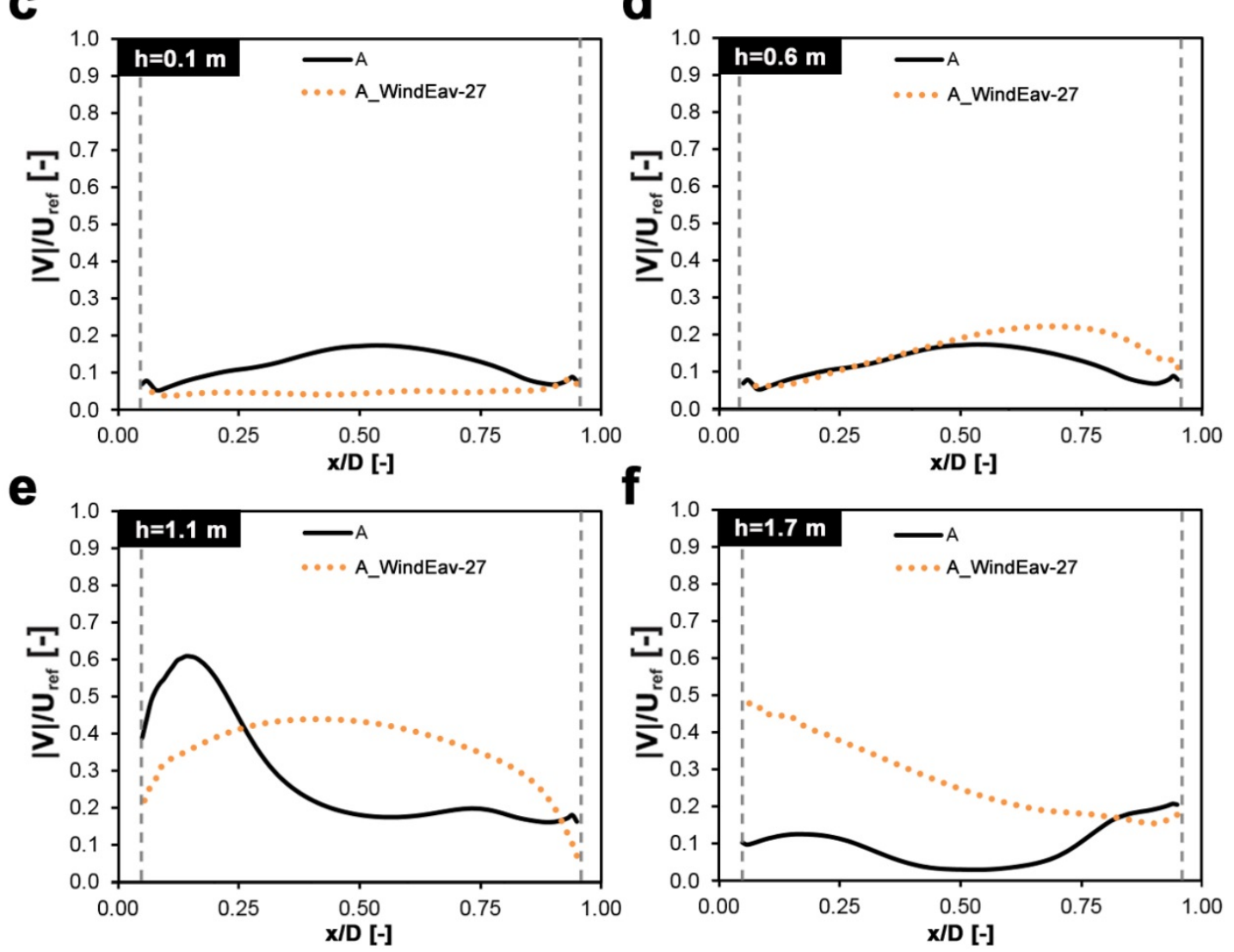

Fig. 7. (a) Impact of the windward eave inclination angle on the volume flow rate under normal wind incidence angle; (b) Eaves configurations and location of the four horizontal lines. (c-f) Non-dimensional velocity magnitude $\left(|\mathrm{V}| / \mathrm{U}_{\text {ref }}\right)$ for cases A and A WindEav-27 along four horizontal lines at a height $h$ above the floor: (c) $h=0.1 \mathrm{~m}$. (d) $\mathrm{h}=0.6 \mathrm{~m}$. (e) $\mathrm{h}=1.1 \mathrm{~m}$ (f) $\mathrm{h}=1.7 \mathrm{~m}$. The dashed vertical lines indicate the inner surface of the walls at the windward and leeward side of the building. 


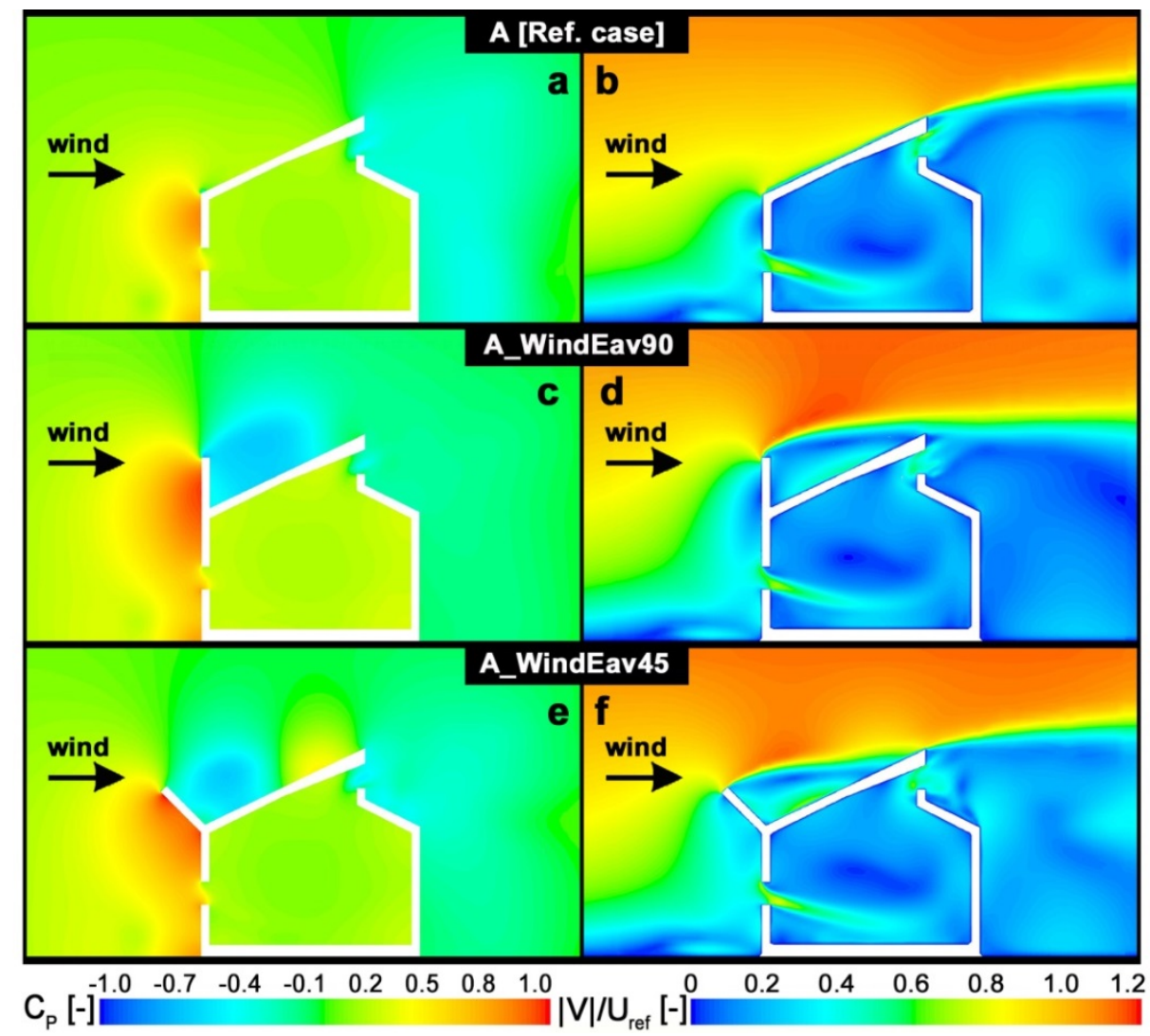

Fig. 8. Contour plot of the pressure coefficient $C_{P}$. $(a, c, e)$ and the non-dimensional velocity magnitude $\left(|V| / U_{\text {ref }}\right)(b, d, f)$ in the vertical center plane for the reference case and for two windward eave geometries: A_WindEav90 and A_WindEav45.

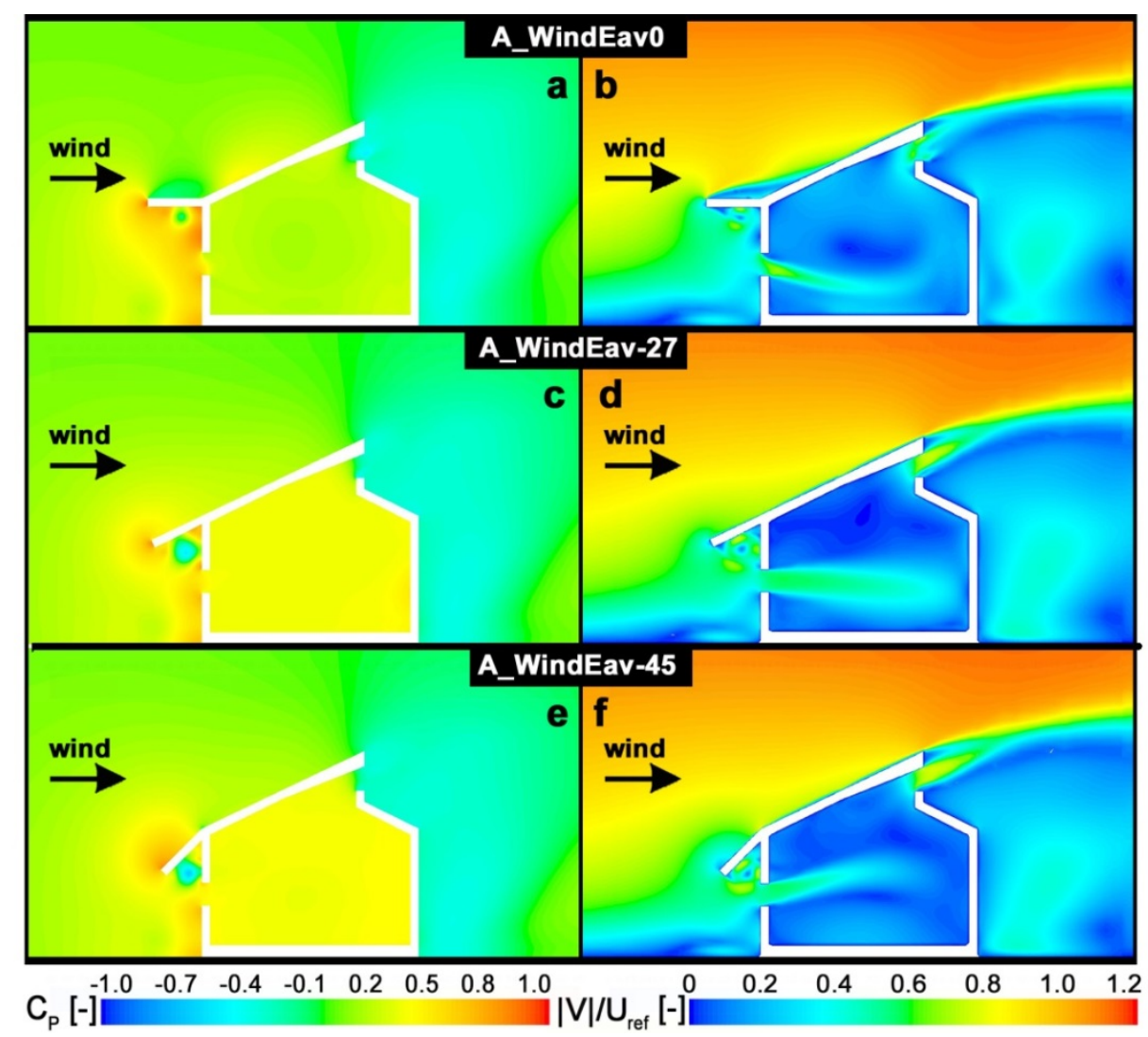

Fig. 9. Contour plot of the pressure coefficient $C_{P}$. $(a, c, e)$ and the non-dimensional velocity magnitude $\left(|V| / U_{\text {ref }}\right)(b, d, f)$ in the vertical center plane for three windward eave geometries: A_WindEav0, A_WindEav-27 and A_WindEav-45. 

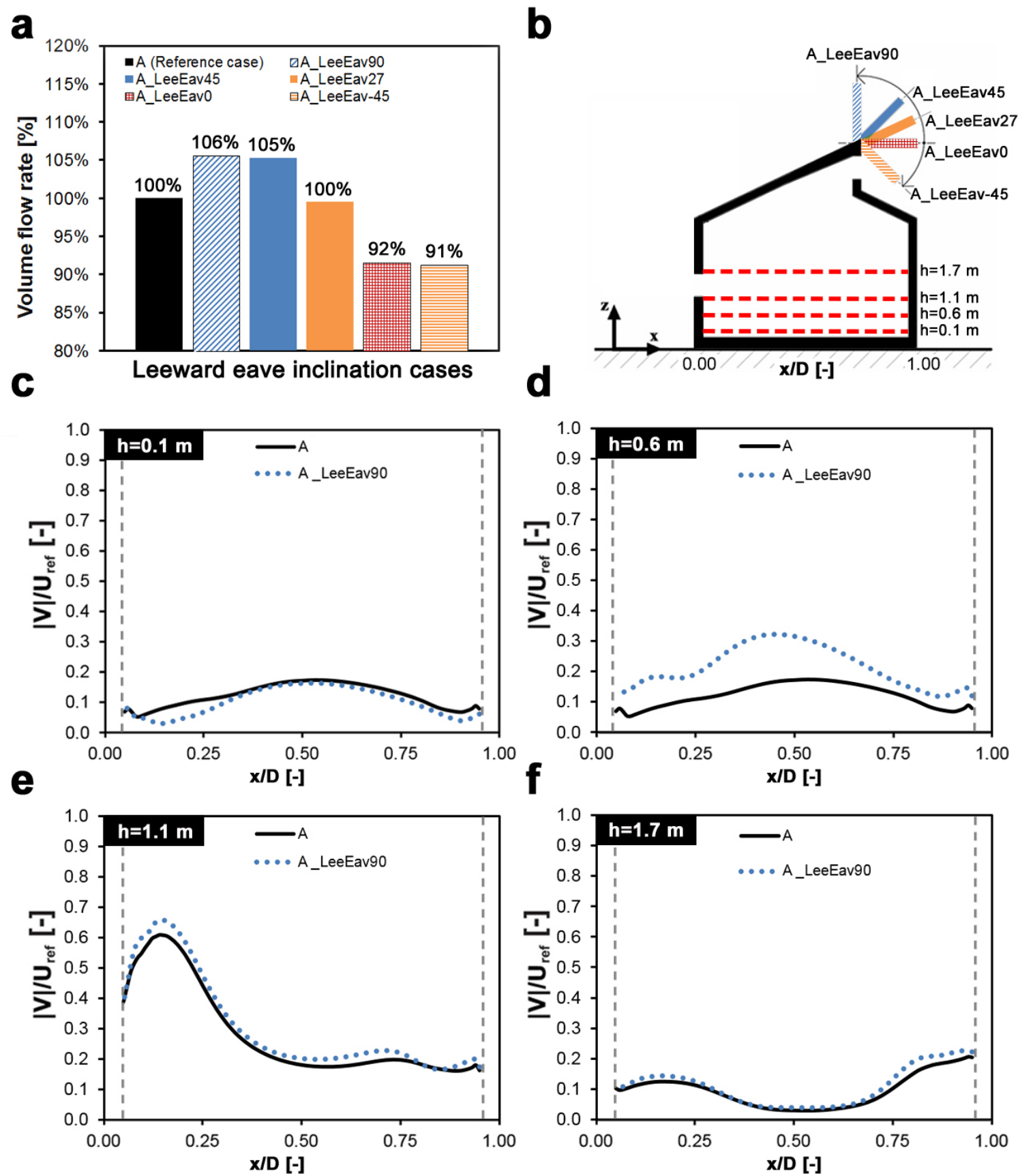

Fig. 10. (a) Impact of the leeward eave inclination angle on the volume flow rate under normal wind incidence angle; Nondimensional velocity magnitude $\left(|\mathrm{V}| / \mathrm{U}_{\text {ref }}\right)$ along four horizontal lines at a height $\mathrm{h}$ above the floor. (b) Location of the four lines. (c) $\mathrm{h}=0.1 \mathrm{~m}$. (d) $\mathrm{h}=0.6 \mathrm{~m}$. (e) $\mathrm{h}=1.1 \mathrm{~m}$ (f) $\mathrm{h}=1.7 \mathrm{~m}$. The dashed vertical lines indicate the inner surface of the walls at the windward and leeward side of the building. 


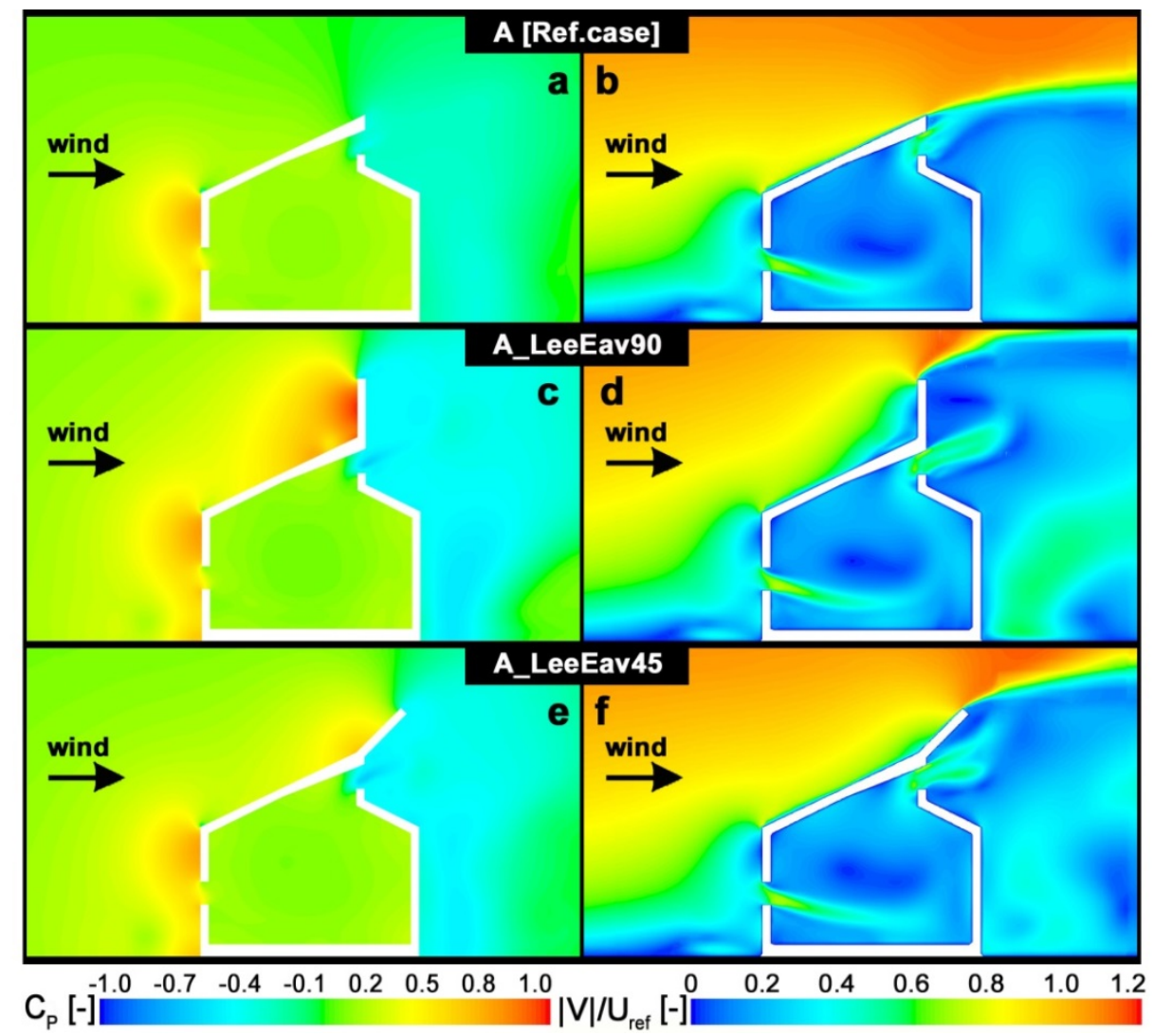

Fig. 11. Contour plot of the pressure coefficient $C_{P}(a, c, e)$ and the non-dimensional velocity magnitude $\left(|V| / U_{\text {ref }}\right)(b, d, f)$ in the vertical center plane for the reference case and for two leeward eave geometries: A_LeeEav90 and A_LeeEav45.

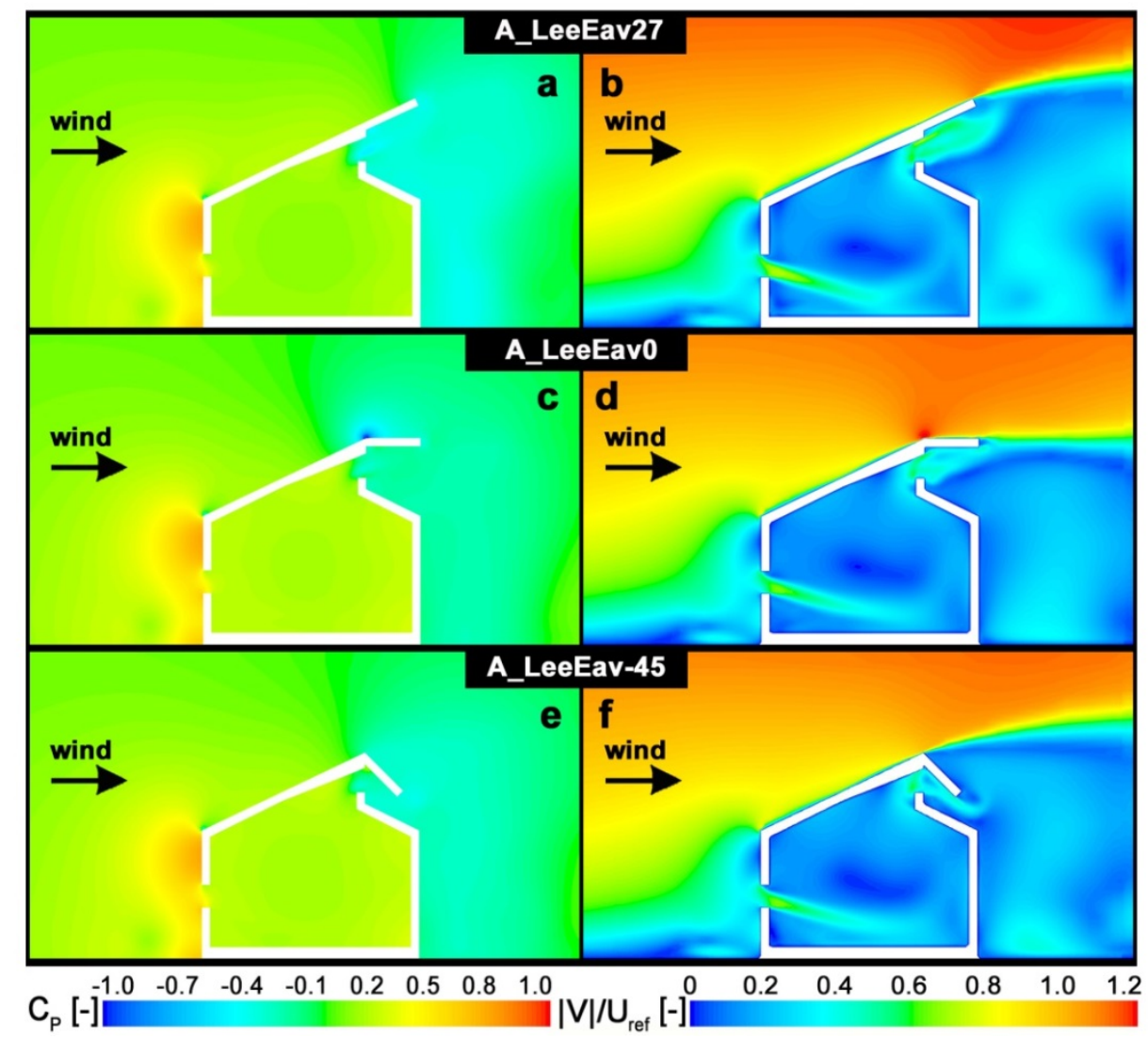

Fig. 12. Contour plot of the pressure coefficient $C_{P}(a, c, e)$ and the non-dimensional velocity magnitude $\left(|V| / U_{\text {ref }}\right)(b, d, f)$ in the vertical center plane for tree leeward eave geometries: A_LeeEav27, A_LeeEav0 and A_LeeEav45. 

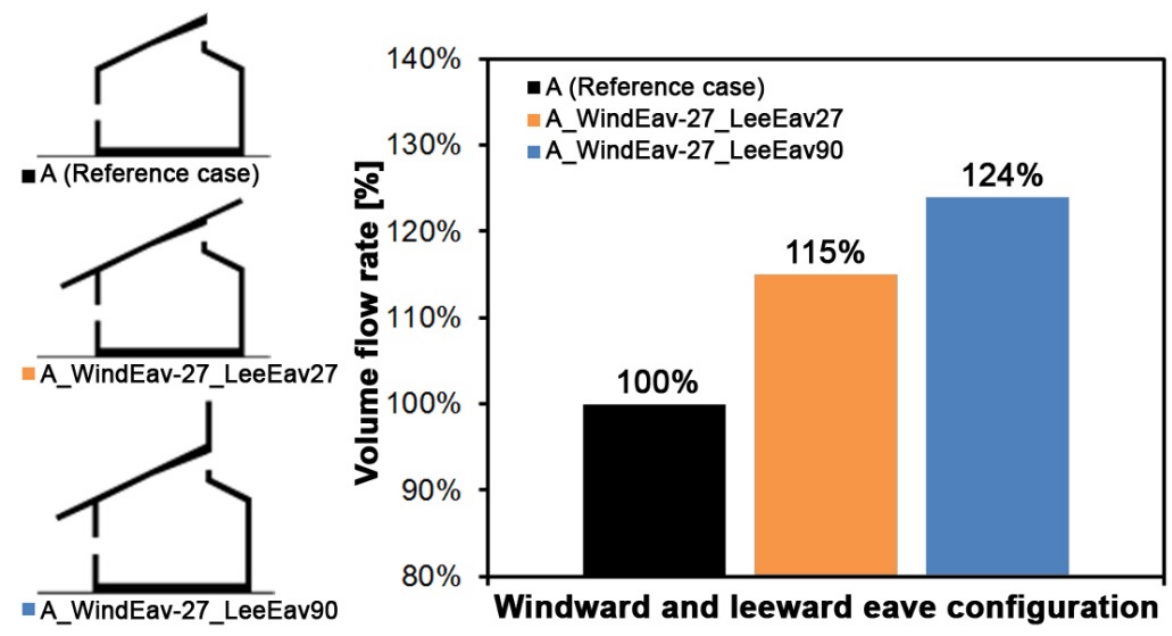

Fig. 13. Influence of the combination of windward and leeward eaves (A_WindEav-27_LeeEav27 and A_WindEav27_LeeEav90) on the volume flow rate.

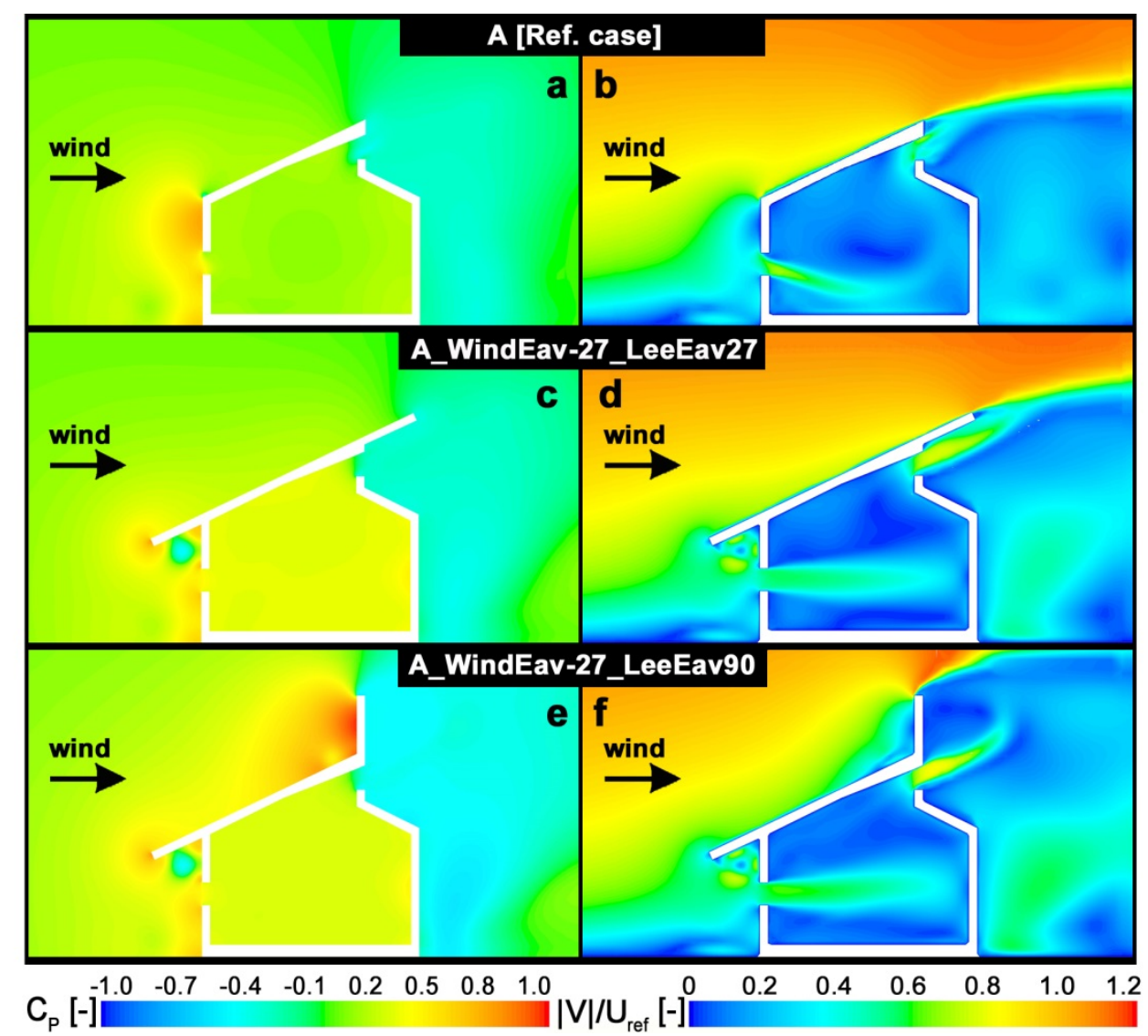

Fig. 14. Contour plot of the pressure coefficient $C_{P}(a, c, e)$ and the non-dimensional velocity magnitude $\left(|V| / U_{\text {ref }}\right)(b, d, f)$ in the vertical center plane for the reference case and for A_WindEav-27_LeeEav27 and A_WindEav-27_LeeEav90. 